\title{
Institutional Affiliation and the Role of Venture Capital: Evidence from Initial Public Offerings in Japan
}

\author{
Working Paper 171
}

\author{
Yasushi Hamao \\ Marshall School of Business \\ University of Southern California \\ Los Angeles, CA 90089-1421 \\ Phone/Fax 213-740-0822/310-450-5875 \\ E-Mail: hamao@usc.edu \\ Frank Packer \\ Capital Markets Department \\ Federal Reserve Bank of New York \\ 33 Liberty Street, New York, NY 10045 \\ Phone/Fax 212-720-6320/212-720-1773 \\ E-Mail: frank.packer@ny.frb.org
}

Jay R. Ritter

Warrington College of Business Administration

University of Florida

Gainesville, FL 32611-7168

Phone/Fax 352-846-2837/352-392-0301

E-Mail: ritter@dale.cba.ufl.edu

http://www.cba.ufl.edu/fire/faculty/ritter.htm

We thank Daiwa Securities, Nippon Investment \& Finance, Takuro Isoda, and Atsushi Harada for providing part of the data and information about venture capital in Japan, and Mingzhu Wang and Sabina Goldina for research assistance. The authors would also like to thank Jean Helwege, Takashi Kaneko, Josh Lerner, Tim Loughran, Robert McCauley, Bill Megginson, Curtis Milhaupt, and Rene Stulz for helpful comments on earlier drafts. The views expressed in this paper are those of the authors' and not necessarily those of the Federal Reserve Bank of New York or the Federal Reserve System. 


\title{
Institutional Affiliation and the Role of Venture Capital: Evidence from Initial Public Offerings in Japan
}

\begin{abstract}
The presence of venture capital in the ownership structure of U.S. firms going public has been associated with both improved long-term performance and lower underpricing at the time of the IPOs. In Japan, we find the long-run performance of venture capital-backed IPOs to be no better than that of other IPOs, with the exception of firms backed by foreign-owned or independent venture capitalists. Many of the major venture capital firms in Japan are subsidiaries of securities firms that may face a conflict of interest when underwriting the venture capital-backed issue. When venture capital holdings are broken down by their institutional affiliation, we find that firms with venture backing from securities company subsidiaries do not perform significantly worse over a three-year time horizon than other IPOs. On the other hand, we find that IPOs in which the lead venture capitalist is also the lead underwriter have higher initial returns than other venture capital-backed IPOs. The latter result suggests that conflicts of interest influence the initial pricing, but not the long-term performance, of initial public offerings in Japan.
\end{abstract}


Institutional Affiliation and the Role of Venture Capital:

Evidence from Initial Public Offerings in Japan

\section{Introduction}

Venture capitalists are increasingly recognized as financial intermediaries that overcome problems of moral hazard and asymmetric information in financial markets (Gompers (1995), Lerner (1995)). Empirical work focusing on the underpricing of initial public offerings (IPOs) suggests that venture capitalists in the United States, who take concentrated equity positions in the issuing firm and retain significant portions of their holdings subsequent to the IPO, are associated with a reduction in the underpricing of new issues (Megginson and Weiss (1991)). Lower initial returns have been viewed as due to venture capital's role in the certification of IPOs, and the reduction of information asymmetry between inside and outside investors.

An alternative to the certification framework does not assume equilibrium, but instead permits the possibility that issuing firms and their financial advisors have some marketing power, with which they can influence either the offer price, the (short-run) market price, or both. This framework assumes that not all investors are sufficiently skeptical about firm quality, with the result that "hyping" a stock can be successful. (See Forsythe, Lundholm, and Rietz (1999) for experimental evidence that hyping a stock can be successful, and Lang and Lundholm (1999) for empirical evidence in the context of seasoned equity offerings.)

Brav and Gompers (1997) report that venture capital-backed IPOs, unlike other IPOs, do not significantly underperform over the long term, suggesting that reputational concerns may constrain their actions. Reputational concerns may also be responsible for the fact that potential conflicts of interest on the part of venture capitalists appear to play little role in the pricing and performance of U.S. IPOs (Gompers and Lerner (1997)). A number of U.S. venture capital firms are subsidiaries of investment banks. If chosen as the lead underwriter, these investment banks have increased incentives to overstate the value of the IPO to investors. Gompers and Lerner, however, find no evidence that the offerings underwritten by affiliated investment banks perform 
significantly worse over the long-term than other venture capital-backed issues.

In this paper, we present tests of the "certification" and "conflict of interest" hypotheses. The evidence is from Japan, a country where venture capitalists frequently take stakes in firms prior to their IPO on the over-the-counter (OTC) market. We use a sample of IPOs that took place on Japan's OTC market between 1989 and 1995. We concentrate on the OTC market for three reasons: (1) Tokyo Stock Exchange-listed IPOs tend to be large offerings of mature firms, and in some cases represent the privatization of state-owned enterprises, for which venture capitalists do not play any role, (2) pure IPOs on stock exchanges (i.e., excluding transfers from the OTC to exchanges) occur much less frequently, and (3) just as Nasdaq is the primary venue for IPOs in the U.S., during the last decade the OTC market has become the primary venue in Japan.

In a related study, Packer (1996) has examined the association of venture capital with the initial returns of 158 Japanese IPOs on the OTC between 1989 and 1991. Our study expands his sample considerably, including nearly 300 additional IPOs that took place between April 1991 and December 1995. In addition, this study also explores the relation between venture capital investment and long-term IPO performance. While our main focus is on the role of venture capitalists in the IPO market, this is the first study of the long-run performance of Japanese firms going public in the OTC market. We use a combination of pricing and returns information that was previously unavailable to nonpractitioners.

Of the 456 IPOs in our sample, nearly one-half had at least one venture capitalist as one of the firm's top 10 shareholders prior to the IPO. Unlike the U.S., venture capitalists are only rarely independent. Instead, they are usually affiliated with major financial institutions such as securities companies or banks.

Venture capitalists that are owned by securities companies have the potential to present a conflict of interest of the sort discussed above. In all of the cases of our sample of Japanese IPOs in which the lead venture investor has a securities company parent, the related securities firm was part of the underwriting syndicate. In three-quarters of the cases, it was the lead underwriter. As an owner of the issuing company, the lead underwriter has an incentive to market an issue more aggressively and set a higher offer price than it would if it was acting solely as a financial 
intermediary. If this conflict of interest were important but not fully recognized by investors, we would expect the IPOs where the lead underwriter was also the lead venture capitalist to exhibit exceptionally poor long-run performance.

Equilibrium models based upon certification and screening predict that both the offer price and the market price should be at higher levels for "certified" issues, and the difference between the offer price and the market price should be less. Equilibrium models, by definition, predict no abnormal returns beyond the initial return period. If there are concerns about conflicts of interest, this should show up in increased underpricing and reduced price-earnings (P/E) ratios. Since information asymmetries deal with unobservable information, a stock which is discounted by the market would have a lower P/E ratio, holding other observable variables constant. In this paper, we examine both the P/E ratios of IPOs relative to comparable firms, and the long-term performance of IPOs relative to comparable firms. We also examine the short-run underpricing patterns. In Figures 1-3, we summarize the predictions of the conflict of interest and certification frameworks for P/E ratios (Figure 1), long-run performance (Figure 2), and short-run underpricing (Figure 3).

Bank-affiliated venture capital does not present the same conflict of interest that securities firm-affiliated venture capital does, since commercial banks do not directly underwrite equity offerings in Japan. Because of a lending relationship with the issuer, it is possible that a bank-related venture capitalist will have better information than other venture capitalists. In the U.S., there is less underpricing when the firm has bank loans outstanding (James and Wier (1990)). Corporate bond issues in the U.S. underwritten by the Section 20 subsidiaries tend to have lower yield spreads at issue for risky firms when the related bank has a loan stake in the firm (Gande, Puri, Saunders, and Walter (1997)). For Japan, Hamao and Hoshi (1999) find similar results. This evidence is important because yield spreads are a measure of valuation. Bank-related venture capital is more long-term than that of other venture capitalists in terms of continuing to hold shares after the IPO. In the U.S., Field (1996) has found that IPOs with substantial institutional holdings post-IPO tend to outperform other IPOs. It is also possible that IPOs with backing from a bank-related venture capitalist may exhibit better long-term performance than other IPOs. In the U.S. bond market before Glass Steagall, both Puri (1996) 
and Kroszner and Rajan (1994) find that bank underwritten issues were likely to result in fewer defaults than other bond issues. ${ }^{1}$

Another form of shareholding which we examine along with that of venture capital is direct bank shareholding. Unlike the U.S., banks can own significant equity shares (up to 5 percent of any single company) in Japanese firms. We also investigate the special role of keiretsu banks. A number of empirical studies have documented that the impact of a bank relationship in Japan can differ if it is a relationship with a keiretsu bank. Hoshi, Kashyap, and Scharfstein (1990) have found that firms in financial distress with a keiretsu bank affiliation are more likely to maintain investment levels, while Prowse (1990) presents evidence that keiretsu banks with substantial debt and equity stakes mitigate the agency costs of debt. It is possible that the role of banks in influencing the pricing and/or long-term performance of IPOs is greater for keiretsu banks than it is for other banks, because of the potential access to even greater inside information about firm quality than a non-keiretsu bank. Dewenter, Novaes, and Pettway (1997) find that, for a sample of Tokyo Stock Exchange (TSE)-listed IPOs, keiretsu-linked IPOs have higher initial returns and somewhat worse long-run performance than other IPOs.

Our principal empirical findings are as follows. First, we document average initial returns of $15.7 \%$ on 456 OTC IPOs from April 1989-December 1995. Pettway and Kaneko (1997, Table 2) report an average initial return of $12.7 \%$ for 69 TSE IPOs over the identical time period. We document average three-year buy-and-hold returns of $-38.9 \%$ for 355 IPOs from April 1989 to December 1994, with nonissuing firms matched on size and industry having average three-year buy-and-hold returns of $-28.2 \%$. This results in a wealth relative of 0.851 $(=0.611 / 0.718)$. In other words, investing an equal amount in each of the IPOs would have left an investor with 85 percent as much wealth 3 years later than if the money had been invested in nonissuing firms. This three-year wealth relative is virtually identical to that reported by Cai and Wei (1997) for TSE-listed IPOs from 1989-1992 using an assets- and industry-matched benchmark.

Second, in contrast to the U.S., venture capital-backed firms on the whole perform neither better nor worse than non-venture backed firms. When we distinguish venture capitalists by parental affiliation, the results differ somewhat. Firms whose lead venture capitalist is either 
foreign-owned or independent perform noticeably better long-term than other IPOs. However, firms whose lead venture capitalist is affiliated with a securities company do not perform noticeably worse long-term than other IPOs.

Third, consistent with Packer (1996), initial returns for venture capital-backed IPOs differ depending on institutional affiliation. While all of the other forms of venture capital appear to lead to lower initial returns-- consistent with venture capital alleviating informational uncertainty about the IPO at the time of issue-- IPOs backed by venture capitalists whose parent is the lead underwriter do not have lower initial returns. Since we did not observe long-term underperformance for this class of IPOs, this result is consistent with investors demanding more underpricing to compensate for the potential conflict of interest.

Fourth, venture capital investment through bank subsidiaries appears to have an impact on underpricing distinct from that of direct bank investment. Bank-related venture capital investment is related to decreased underpricing, but this is not apparent in the case of direct bank investment. Neither form of bank investment affects long-term performance relative to that of non venture capital-backed firms.

Finally, whether the bank is a keiretsu bank does not appear to influence the impact that bank-related venture capital or direct bank investment has on either underpricing or long-term performance.

LaPorta et al (1999) argue that unregulated financial markets do not work well. Our findings suggest that, while reputation effects constrain the behavior of financial intermediaries faced with a conflict of interest in underwriting securities where they have an ownership stake, reputation effects may not completely overcome the conflicts of interest. Thus, unlike the conclusions from much of the academic literature using U.S. data, regulatory constraints may offer protection to investors who otherwise may be too gullible. Whether this is specific to Japan or not is an open question. Kang and Stulz (1996) conclude, for instance, that Japanese managers decide to issue shares based on different considerations than American managers.

In the next section, we outline the relative importance of the OTC market in Japan, our principal data source for this paper, and changes in the regulatory regime governing IPOs. In section 3, we examine and quantify the types of holdings in privately held companies by venture 
capital prior to the initial public offering. We highlight differences in investor behavior after the IPO by investor class. In section 4, the sample and data sources are introduced in detail, as well as the methodology. Section 5 presents statistical evidence concerning the influence of the different types of shareholding stakes on new issue underpricing, the long-term performance of IPOs, and P/E ratios relative to comparable firms. We end with a brief summation of our results and suggestions for future research in section 6.

\section{The OTC Market and Changes in the IPO Regulatory Regime: 1989-1995}

\subsection{The OTC Market}

The recent history of initial public offerings in Japan has been characterized by the increasing importance of the over-the-counter market. In 1983, the Ministry of Finance relaxed regulations to allow companies to raise equity capital through the over-the-counter market. Firm age and per share dividend requirements were abolished, and a per-share profit requirement was relaxed from 10 yen per share after-tax to 10 yen per share before-tax. Requirements for the

number of shares in the public float, shareholders, years with audited financial statements, years with dividend payments, and the amount of profits were already much lower than those of the Tokyo Stock Exchange (TSE).

By the late 1980s, the OTC had become the central market for initial public offerings in Japan. Between April 1989 and December 1995, while Pettway and Kaneko (1997) report that 69 firms publicly issued equity concurrent with a listing on the TSE, our sample of OTC IPOs totals more than 456 firms (Table 1). The OTC offerings in our sample tend to be fairly large, with mean gross proceeds of 4.8 billion yen, although of modest size relative to mean gross proceeds of 18.2 billion yen for Pettway and Kaneko's sample of TSE IPOs. (The yen/dollar exchange rate averaged about 120 yen per dollar during our sample period.)

Firms that go public in Japan, including firms on the OTC, are much older on average than those that go public in the U.S. The average age of firms going public in our sample is 35 years; by contrast, the average age of the 640 firm sample of U.S. IPOs from the mid-1980s studied in Megginson and Weiss (1991) was just over 10 years. The relatively high age numbers may be due in part to the requirement in Japan that firms show profits prior to going public. 
Though less demanding for OTC IPOs than the TSE, each firm in our sample was required to show minimum pre-tax profits of 10 yen per share (and at least 1 million shares were to be outstanding prior to the IPO). There also was a paid-in capital minimum of 200 million yen (about $\$ 1.7$ million). ${ }^{2}$

\subsection{Changes in Regulations}

The underpricing of initial public offerings in Japan has been well documented and until the 1990s had been much larger than that of the United States. In the 1980s, initial returns averaged 30-50 percent (Hebner and Hiraki (1993)). Underpricing was particularly large between 1986 and 1988. During this period, the first closing market price of issues was around 55 percent higher than the offering price, with average initial returns of nearly 75 percent characterizing the 1988 market (Jenkinson (1990)). These large initial returns became the target of public criticism during the Recruit scandal in which certain politicians, who were the recipients of preferentially allocated shares, made large capital gains. The scandal served as a stimulus to reform and led to a new system governing IPOs being implemented in April 1989. ${ }^{3}$

Prior to reforms, the offering price for an IPO had been determined around 20 days prior to the offering date by comparing its financial ratios with those of a comparable listed company. The comparable company was chosen by the lead underwriter. The ratio of the offer price of the IPO to the share price of a comparable company was the simple average of the ratios of dividends, earnings, and book value per share to those of the comparable company. However, the underpricing that resulted suggests that the competitive pressures on securities companies to choose appropriate comparable companies were limited.

In the 1989 reform, the Ministry of Finance decided to continue using a method based on the share price and financial ratios of a comparable company (though dropping dividends per share from the formula). However, the value that resulted was only to serve as a floor on the subsequent offer price. $30-40$ percent of the shares being sold would be auctioned off in a discriminatory auction fully open to the public where a maximum limit price of 30 percent above the floor price was also established. The balance was to be sold at an offer price equal to the weighted average of successful bid prices. ${ }^{4}$ The first-stage auction occurred two weeks before the public offering of the balance and data such as the total amounts bid and the settlement price 
were released to the public on the day of the auction.

Auctions began in April 1989, and the evidence from TSE- and regional exchange-listed IPOs, presented by Hebner and Hiraki (1993), is that average initial returns decreased from 34 percent to 21 percent. For our sample of 206 IPOs made on the OTC between April 1989 and March 1992, Table 1 reports an average initial return of 19.8 percent. Between April 1989 and March 1991, more than 50 percent of the first-stage auctions resulted in rationing at the upper limit price, suggesting that even after allowing for a value 30 percent greater than the price reached by a comparable company method, the offer price determined by the first-stage auction procedure did not reflect initial demand (Packer (1996)).

In mid-December 1991, after a sharp market downturn, and a month-long period in which the first trading price was lower than the public offering price for more than half of around 30 IPOs, regulators temporarily closed down the IPO market. The next new listing on the OTC market occurred in late May 1992.

As the narrow band for the first-stage auction was particularly costly to underwriters in a down market, and there was a lack of a strong rationale for maintaining the band, the rules regarding the setting of the offer price were revised twice within a year. First, starting in April 1992, the minimum bid price for auctions of newly listed stock was dropped from 100 percent to 85 percent of the "theoretical price" based on related companies, and the ceiling on the bids in the auction was removed. Second, starting in January 1993, the lead underwriter was allowed to discount the issue from the initial offer price determined at the auction. Initial returns on IPOs subsequent to this combination of revisions, through the end of our sample period in 1995 , averaged 12.3 percent (Table 1), a significantly lower level than in 1989-1991.

Table 1 also reports the mean 3-year holding period return for the IPOs, and the mean 3year return in excess of that realized by an industry- and size-matched non-IPO portfolio (the matching procedure is described more fully in section 4). The holding period returns are calculated from the first market price of the IPO. The table also reports the 3-year wealth relative-- determined by dividing the average gross 3-year holding period IPO return by the average gross return of industry- and size-matched firms.

Inspection of Table 1 reveals that in two of the cohort years of our sample, 1989 and 
1991, IPOs on the OTC in Japan had average excess returns that were positive; however they were only $0.2 \%$ and $1.5 \%$, respectively. For all IPOs issued during April 1989-March 1992, the 3-year holding period return averaged $-51.1 \%$, around $7 \%$ less than the industry and size-matched firms, giving a wealth relative of 0.892. For IPOs issued during April 1992-December 1994, while the mean 3-year return was nearly identical, the wealth relative is only 0.799 . The overall 3-year wealth relative of 0.851 is just under that of 0.86 documented for IPOs from 1989 to 1992 on the Tokyo Stock Exchange (Cai and Wei (1997)), and somewhat above the 0.80 documented for IPOs in the U.S. between 1970 and 1990 in Loughran and Ritter (1995) using size-matched firms. Thus, the long-term underperformance of initial public offerings is apparent in our sample, as it has been in the majority of studies around the world (see Loughran, Ritter, and Rydqvist (1994)).

Starting in September 1997, after our sample period for Japanese IPOs, both the OTC and the Tokyo Stock Exchange offered firms and their underwriters the option of instituting a bookbuilding process for the determination of the initial offer price instead of the first-stage auction. Book-building rapidly displaced auctions as the principal means of determining offer prices for IPOs. Apparently, there was a strong demand from underwriters for alternatives to the auction system.

\section{Types of Venture Capital in Japan and Bank Shareholding}

\subsection{Venture Capital in Japan}

There are significant differences between venture capital in Japan and the United States.

For one, the industry is more concentrated than in the United States. Of the aggregate investment portfolio of 877 billion yen reported by the respondents to a 1997 survey of major venture capital firms, the top 4 firms accounted for 46.1 percent, while the top 10 accounted for 66.5 percent (Nikkei Kinyu Shimbun (1997)). Secondly, venture capital companies which invest in unlisted companies tend to be relatively young. The first private venture capital firms in Japan were established in the early 1970s. The median year of establishment for the ten largest private venture capital firms listed in the above-mentioned survey is 1983.

One striking characteristic of Japanese venture capital is that none of the leading venture 
capital firms are independent. Among the top twenty-five venture capital firms listed in the Nikkei survey, 11 were the affiliates of banks, and 8 were the affiliates of securities firms; the rest were either semi-governmental institutions (3), the affiliates of non-bank financial institutions (2), or the affiliate of a software company (1). ${ }^{5}$

Unlike the United States, where many venture capitalists specialize in taking an active role in the financing and advising of young companies, venture capital investing in Japan is not associated with an active monitoring role. In fact, until 1995, the anti-monopoly law prohibited employees of a venture capital firm from being on the board of directors of a firm that it invested in. Venture capital's relatively inactive role in the governance of the firm is paralleled by a pattern of providing financing relatively late in the life cycle of portfolio companies. The Ministry of International Trade and Industry's (MITI) estimate of the percent of new Japanese venture capital funding during fiscal year 1995 that went to startup firms is 3 percent, much lower than the 30 percent reported for U.S. venture capital. At the other extreme, 38 percent went to firms over 20 years of age (Venture Enterprise Center (1997) and Isoda (1997)). Consistent with the tendency to invest in relatively mature companies, there is no strong hightech bias in venture capital investments in Japan, unlike the U.S.

While Japanese venture capitalists may fund more established firms and provide less managerial advice, they still generally invest with the objective of holding on to the shares until the company goes public. According to an estimate of Isoda (1997), 58 percent of the venture capital investment in Japan, on an investment-cost weighted base, results in an IPO. The comparative numbers for U.S. and European venture capital are 47 percent and 31 percent. The Japanese percentage is relatively high due to the aversion to investments in startups, which are more likely to result in disposition via bankruptcy or acquisition at a fire-sale price.

\subsection{Characteristics of Venture Capital-backed IPOs}

The presence of venture capital in Japanese IPOs is clearly evident in Table 2 when we examine the ownership of our sample of 456 firms which went public in Japan between 1989 and 1995 on the OTC market. 210 firms, or 46 percent, have a venture capitalist among the top 10 shareholders prior to listing.

Table 2 also compares the characteristics of these venture capital-backed IPOs with the 
rest of the IPO sample. The size of the IPO, as measured by gross proceeds, averages 4.2 billion yen (about \$35 million U.S.) for venture capital-backed IPOs; the median is 2.6 billion yen. Both the mean and median are significantly smaller than those of the non-venture IPOs. Similar to the U.S., venture-capital backed IPOs tend to be younger than other IPOs.

Underpricing of venture capital-backed IPOs tends to be greater than that of other IPOs in Japan. The mean of 19.2 percent and median of 8 percent are both significantly higher than those of other IPOs. While this pattern was not found in the U.S. (See Megginson and Weiss (1991, Table VI) and Barry, Muscarella, Peavy, and Vetsuypens (1990, Table 4)) for IPOs from the 1980s, we show below that in the 1990s, the U.S. pattern has become more similar to that of Japan. Increased underpricing on average might suggest that venture capital does not alleviate informational problems by certifying the quality of the IPO firm. In our regressions to be reported later, we will control for other firm-specific variables such as size and age, which may affect underpricing independently of venture capital participation.

The book-to-market measures are not significantly different between venture capitalbacked and other IPOs, and the means and medians of the 3-year returns, excess returns, and wealth relatives are also not statistically different. During our sample period, IPOs in Japan have been a relatively poor investment regardless of whether they had venture capital-backing or not.

Table 3 reports that the average stake of the lead venture capitalist is 5.92 percent, less than one-half of the participation documented in similar studies of the United States. On average, the post-IPO equity share held by the lead venture capitalist declines by around 40 percent of the pre-IPO share. Since the increase in the number of shares outstanding from a public offering is limited to 30 percent, this implies that some cashing out by the venture capital investors occurs either during the offering or its immediate aftermath. This pattern differs from that in the U.S., where venture capitalists rarely sell shares in the IPO (Barry et al, 1990).

\subsection{Small Business Investment Companies.}

There appear to be distinct patterns in the behavior of venture capital depending on institutional affiliation. The oldest venture capital firms in Japan are the semi-governmental institutions. In 1963, Small Business Investment Companies (SBIC) were set up in Tokyo, Nagoya, and Osaka by the enactment of the Small Business Investment Law under MITI's 
initiative. Capital was contributed into these SBICs by both local government institutions and local financial institutions and companies. Regulations limited their investment to small, yet profitable, dividend paying companies, and further required that the investment be at least 15 percent of the total equity (Clark (1988)).

Because of their early start, the investments outstanding of the three SBICs are relatively large, and the Tokyo and Osaka SBICs were ranked 7th and 9th in the 1997 Nikkei survey of venture capital firms, based on outstanding investments. The fruits of past SBIC investment decisions are evident in our sample of IPOs. Table 3 indicates that they were the leading venture capitalist in 24 out of the 210 cases in which pre-IPO venture capital funding occurred. A distinctive feature of SBIC cases is that they are the leading venture capital shareholder in almost every case in which their investment appears. This phenomenon reflects the minimum shareholding requirement at the time of the investment. By the time of the IPO, however, they usually hold less than 15 percent, since other private equity investments occurred between their investment and the time of the IPO.

\subsection{Securities Company-Affiliated Venture Capital.}

Another class of players in the Japanese venture capital industry are those companies which are affiliates of a Japanese securities company. Five out of the top ten, and eight out of the top twenty-five, firms in 1997 were affiliated with securities companies. A striking parallel with the securities industry is the dominance of one firm (Table 4). Nomura Securities' affiliated subsidiary, Japan Affiliated Finance Company (JAFCO) accounted for 21.7 percent of the reported stock of investment by private venture capital in Japan in 1997. In addition to its market share dominance, JAFCO is also the only venture capital firm which has publicly traded shares.

Securities firm-affiliated venture capitalists are the most numerous in the pre-IPO investment ledger of our sample (Table 3). 99 of the 210 firms with venture capital funding had as their lead venture capitalist one that was affiliated with a securities firm. Another 32 had one as a secondary provider of venture funds. Thus, more than 28 percent of the entire IPO sample, and 60 percent of the venture capital-backed sample, had a securities firm-affiliated venture capitalist among their top ten shareholders.

Venture capitalists affiliated with securities companies may intend to obtain the lead 
underwriter position for the parent if the company goes public. It is customary for the managing underwriter to underwrite around 40-60 percent of the issue itself compared to 25-35 in the U.S. (Sutton and Benedetto (1990)). Thus, it obtains most of the gross spread, which is customarily set at about $3.5 \%$ of the offer price. In Table 4, the relationship between venture capital participation and the position of the lead underwriter is documented for our sample. A company with a securities company-affiliated venture capitalist among its top ten shareholders chooses that company as its lead underwriter more than 75 percent of the time.

In the analysis to follow, we will be examining whether the impact of securities firmaffiliated venture capital investment differs if the venture capitalist is also affiliated with the lead underwriter. There is reason to believe that a managing underwriter may have better information about the quality of the firm. ${ }^{6}$ At the same time, the lead underwriter faces a greater conflict of interest when it also holds a stake in the firm through a venture capital subsidiary. The managing underwriter may have an increased incentive to market the issue and generate overly optimistic forecasts of the firm's prospects. The greater tendency of securities firm-affiliated venture capital to cash out at the IPO merely exacerbates this conflict of interest.

Of course, there is also the possibility that concerns over reputation may constrain the securities company and/or related venture capitalist from overpricing an IPO. Gompers and Lerner (1997) have found no evidence that the conflicts of interests between underwriter and their captive venture capital subsidiaries affects either after-market performance of IPOs or the magnitude of underpricing at issue. In the context of underpricing alone, Beatty and Ritter (1986) have found evidence that the market "punishes those underwriters who cheat." Carter and Manaster (1990) and others have found empirical evidence of significantly negative relations between underwriter prestige and the magnitude of underpricing. ${ }^{7}$

\subsection{Bank-Affiliated Venture Capital.}

The third major class of players in the Japanese venture capital industry are companies which are affiliates of Japanese banks. Two out of the top ten, and eleven out of the top twentyfive firms in the industry, are affiliated with commercial banks. In our 456 firm IPO sample, the presence of bank venture capital subsidiaries among the top ten shareholders is almost as frequent as that of the securities firm subsidiaries (Table 3). More than one-third of the 210 
venture capital-backed IPOs have a bank subsidiary as their lead venture capitalist prior to the IPO.

Bank-affiliated venture capital involvement appears to be somewhat more long-term oriented than its securities company-affiliated counterpart. The percentage of equity held by the lead venture capitalist increases from $4.3 \%$ pre-IPO to $4.5 \%$ afterwards (Table 3). Bankaffiliated venture capital shareholding is often associated with a lending relationship. In more than one-half of the cases of bank-affiliated venture capital investment, the related bank is listed as the top transaction bank. Holding shares in the firm is sometimes viewed as a mechanism through which Japanese banks reduce the agency costs associated with debt (Prowse (1990), Aoki (1988)). Bank shareholding through venture capital subsidiaries may also be of relevance to the costs of information asymmetries in going public as well.

\subsection{Foreign and Independent Venture Capital}

The final class of venture capital firms are either foreign or independent. IPO firms with foreign or independent venture capital involvement comprised less than $10 \%$ of all IPOs (Table 3). Cases in which the lead venture capitalist fell into this category were distinct in two respects. First, the foreign/independent venture capitalist tended to own a larger share of the firm prior to the IPO -- 8.4\% on average -- than either bank- or securities firm-affiliated venture capitalists. Second, the foreign/independent venture capitalist, when it was the lead, tended to be a part of a larger syndicate. The mean number of venture capitalists as major shareholders, 1.9 , and the mean percentage of equity held by all venture capitalists, $11.5 \%$, are large relative to the other classes of venture capital (Table 3).

\subsection{Direct Bank Shareholding.}

Unlike U.S. banks, which cannot hold stocks of nonfinancial corporations, Japanese banks are allowed to take equity positions in Japanese companies. ${ }^{8}$ Thus, banks may invest in the firm prior to the IPO directly and not just through venture capital subsidiaries. As with that of their venture capital subsidiaries, bank shareholding is usually associated with a lending relationship. In our sample, the lead bank shareholder subsequent to the IPO is listed as the top transaction bank by the firm more than 80 percent of the time.

The recruitment of banks as major shareholders generally occurs well in advance of going 
public, and is usually given high priority in "how to go public" manuals in Japan (Kakitsuka (1989)). The emphasis is usually on the creation of stable shareholders and by extension the minimization of "floating" shareholdings which can fall into unfriendly hands. As stable shareholders, banks are not only expected to hold on to their pre-IPO shares, but also to buy up shares in the offering or after-market to preserve or increase the proportion of their holdings.

In Table 5, we see that the presence of banks as major shareholders for companies going public is more common than that of venture capitalists. 363 firms, or $78 \%$ of our sample, have at least one bank as one of their top ten shareholders prior to going public. The average percent holding for the lead bank is somewhat lower than that documented for venture capitalists -around $2.9 \%$ (remember that any one bank cannot hold more than $5 \%$ of the equity). Keiretsu banks, which are the lead banks around two-thirds of the time, tend to own a little less equity (2.6\%) and tend to be accompanied by fewer banks when they hold shares.

An important difference between direct bank shareholding and the behavior of most of the more formal forms of venture capital shareholding can be seen in the columns that document post-IPO holdings. Not only do more banks on average enter the ranks of the top ten shareholders with a larger aggregate share, but the share of the lead bank shareholder increases subsequent to the IPO to $3.3 \%$ on average. Banks increase their shareholding either during or subsequent to the IPO. Because of this, it is possible that direct bank shareholding may have more credibility as a mechanism of certification than that of the formal venture capital institutions in Japan.

\section{Data and Methodology for Tests Using Returns}

\subsection{Sample Selection and Data.}

Because we only have records of long-term (three-year) performance through December 31, 1997, we restrict our sample for the analysis that follows to those IPOs between April 1989 (the introduction of the auction system) and December 31, 1994. The 101 OTC-listed IPOs from 1995 are not used for our long-term performance analysis.

For each IPO firm, matching listed firms were searched for. First, firms in the same fourdigit industry classification were first chosen from all firms that have been traded (on either the 
OTC market or the Tokyo Stock Exchange) for more than three years. These firms are then divided into deciles according to the market value of equity. We choose firms in the same size decile as the IPO firm to be industry and size-matched firms. If there is more than one qualifying matching firm, we form a portfolio of matching firms. In this matching, we lost 56 firms from our observations because of the lack of a comparable firm, resulting in 355 IPO firms between April 1989 and December 1994. The 3-year excess return is calculated as the three year buy-andhold return for the IPO (from the end of first trading day price) minus the average three-year buyand-hold return over the same period for the matched non-IPO firms. IPO firms that are delisted are included until the date of delisting. Reflecting the relative infrequency of delistings, in no case did a portfolio of matching firms cease to have at least one component firm.

Data on individual daily stock prices and OTC index values are taken from the Nikkei NEEDS electronic database. Shareholding data, firm size and age, as well as identification of the transaction bank and lead underwriter, are taken from various editions of the Japanese language version of the Kaisha Shiki Ho (Japan Company Handbook). Price and quantity information about the auction and initial public offerings were provided by Daiwa Securities, including the number of shares put up for sale, the allowable bid interval, the number of bids submitted, and weighted average of bids (offering price) from the auction.

\subsection{Methodology and Variables Used}

To test our hypotheses, we estimate two sets of regressions using returns. First, we regress the 3-year excess return (over matched firms) on control variables and dummies accounting for different types of IPO shareholding. Second, we estimate the impact of different types of pre-IPO shareholding on the difference between the offering price and the first trading price. We have designed the estimation procedures to control for important institutional features of the IPO process in Japan as well as other factors commonly used in empirical tests of the determinants of the long-term performance and initial return of IPOs.

Size, Book-to-Market, and Age. The first set of equations, estimating the determinants of long-term performance, includes three control variables. We include the natural logarithm of offer proceeds. Smaller firms tend to perform worse in studies of long-term performance in the United States (Ritter (1991), Brav and Gompers (1997)). We also include the natural logarithm 
of the firm's book-to-market equity ratio, based on the first market price of the share subsequent to the IPO and the post-issue book value. Finally, we include the natural logarithm of the age of the firm.

The second set of equations, estimating the determinants of underpricing, includes each of the three control variables discussed above, with the modification that the market value of the book-to-market ratio is estimated using the lower limit of the auction bid range. Issues with greater ex ante uncertainty should be most subject to the winner's curse and thus equilibrium underpricing. Both age and offering proceeds are commonly used proxies for ex ante uncertainty.

The second set of regressions also includes the following additional variables to account for the IPO regulatory regimes.

Auction Results. As explained above, the offering price is determined in an auction of part of the issue, which occurs two weeks before the trading of the issue. During the April 1989 March 1991 period, the offering price was constrained to be within a price range determined by the comparable company method. These results are revealed to all potential subsequent subscribers to the issue. In addition to the offering price (the weighted average of successful bids), the most informative single number is the ratio of the number of total bids submitted at the auction to the number of shares auctioned. This number is particularly important should the issue have been sold out at the upper limit price during the first IPO pricing regime of 19891991, as it proxies for the number of bidders rationed out of the issue on a non-price basis. We include the ratio of this number to the total number of shares issued as a variable ("Subscription Ratio") which we expect to be positively related to expectations after the auction concerning the actual value of the issue. Since the effect of the subscription ratio should differ depending on the allowable bids, we allow the coefficient on the subscription ratio to differ depending on each of the regimes by including three variables, each of which is the subscription ratio during one regime, 0 otherwise.

A problem with using the subscription ratio as an explanatory variable is that it is endogenous: the popularity of the auction may also reflect variables such as ex ante uncertainty as well as the venture capital dummies, and it is likely to be correlated with the disturbance term 
of the equation. Since the OLS estimator is biased, even asymptotically, in this case we use the method of instrumental variables. The instrument is that suggested by the 2SLS procedure. Namely, the subscription ratio is regressed against the three exogenous variables described above, an additional variable which measures market movement over the period between setting of the auction price parameters and the actual auction itself, and the venture capital dummies described below. The estimated values for the subscription ratio which result are then used as the instrumental variable for the subscription ratio.

Institutional Lag. In general there is a time lag between the auction and the formation of an initial trading price of usually two weeks. To the extent that the value of the issue is related to that of the market, market movements in the interim period will affect the initial trading price relative to the offer price. Thus, a variable is included which is the return of the Nikkei OTC index during the time period between the company's auction and formation of an initial trading price. We expect the coefficient on this variable to be positive and significant.

Regime Dummies. As discussed above, there were three distinct IPO regulatory regimes during the period of our sample (1989-1991, 1992, and 1993-1995). The second and third regime are distinguished by fewer constraints on the first stage bidding, and the third regime is distinguished by increased discretion awarded the underwriter to discount the issue from the price reached at the auction if market conditions warranted. We are already controlling for how these regimes may change the influence of the subscription ratio as a predictor of underpricing. We include two straight regime dummies as well to control for any additional impact regime changes had on the absolute level of underpricing.

Venture Indicators. For both the long-term performance and underpricing regressions, we include six different specifications which differ in their combination of variables indicating venture capital participation. In specification (1), we include an indicator variable that equals one if any venture capitalist is on the list of top ten shareholders. Specification (2) is identical to specification (1) except that we include an additional indicator variable which equals one if the IPO also has a direct bank investor among its list of 10 largest shareholders prior to the IPO that is greater than any of the venture capital investors. In specification (3), we include four mutually exclusive indicator variables that equal one if the lead venture capitalist of the IPO was affiliated 
with a securities firm, a bank, an SBIC, or was foreign/independent, respectively. Specifications (4) and (5) include dummy variables measuring whether a securities firm-affiliated venture capitalist was or was not the lead underwriter. In specification (5), we include a dummy variable for whether the IPO also has a direct bank investor among its largest pre-issue shareholders.

In specification (6), we also include seven exclusive indicator variables, but this time divide up the indicator variable for bank-related venture capital backing into one that equals one if the related bank was a keiretsu bank, another equaling one if the related bank was not a keiretsu bank. Two additional indicator variables are added: the first of which equals one if there is a direct keiretsu bank investor among the top ten shareholders that holds more shares than the venture capital investors, the second that equals one if the direct bank investment is from a nonkeiretsu bank.

\section{Empirical Evidence}

\subsection{Sample Summary Statistics.}

In Table 6, characteristics of the firms going public on the OTC in the years 1989-1994 are presented according to the existence and type of venture backing, and the presence of direct bank investment. Since full three-year performance histories are not available for IPOs after 1994, we do not include them in the regression analysis to follow. Striking differences are evident in the summary statistics when we divide up the sample by different types of venture capital.

As shown in Table 6, the firms in which SBICs invest are much older than average (43.2 years as opposed to 33.0 years) at the time of the IPO and have a much smaller issue size. Furthermore, the book-to-market ratio is much higher. The initial return on SBIC-backed issues is generally lower, and the subsequent 3-year excess return and wealth relatives are among the worst of the different venture capital-backed IPO categories.

Venture capital-backed issues in which a securities company affiliate was the lead venture capitalist tend to be slightly younger and somewhat larger. The initial returns and the long-term returns are about the same as for the entire venture capital-backed sample. Firms in which the venture capital backing comes from a firm related to the lead underwriter tend to be larger than 
the others, have only slightly worse long-term performance than the other securities company venture capital-backed IPOs, and initial returns are slightly lower. These results are not suggestive of conflicts of interest which would lead to worse long-term performance and increased underpricing at the time of issue.

New stock issues in which a bank-affiliated venture capital firm is the lead venture capitalist also tend to be slightly younger and somewhat larger than other venture capital-backed IPOs. The initial returns average slightly lower than other venture backed issues, but the longterm excess returns of $-16 \%$ are worse than other venture backed IPOs, with the exception of the SBIC-backed issues. Larger distinctions are apparent from the sample of keiretsu bank-affiliated venture capital-backed IPOs. These tend to be around the same size as other venture-capitalbacked IPOs, but exhibit dramatically less underpricing at the time of issue $(10.2 \%$ versus an average of $20.0 \%$ ). At the same time, the 3-year excess return is about the same as the bankaffiliated venture capital-backed IPO average, though still worse than the entire venture-backed average of $-9.6 \%$.

The one category of venture capital-backed IPOs for which positive excess returns are apparent are those by foreign or independent firms. These firms are also characterized by lower book-to-market ratios and exhibit very high average initial returns.

The final two rows of Table 6 give summary statistics for those cases of direct bank investment in which their holdings exceeded those of the venture capitalists. These IPOs tend to be slightly larger than the venture capital-backed IPOs. They tend to be slightly older, have lower initial returns, and somewhat less negative long-term returns than venture capital-backed IPOs. When we examine IPOs with direct keiretsu bank investment in isolation, they tend to be even larger, have even lower initial returns but more negative long-term returns than other IPOs with direct bank investment. These numbers suggest that the type of firm that banks (both keiretsu and non-keiretsu) invest in directly prior to the IPO differ from the type that they invest in through their venture capital subsidiary. Dewenter, Novaes, and Pettway (1997), in an examination of TSE-listed IPOs, find that IPOs affiliated with a keiretsu bank have higher initial returns, a finding that contrasts with our results.

\subsection{Determinants of Long-Term Performance.}


Table 7 reports the results of the six specifications of the long-term performance regressions discussed in section 4.2 above. In an attempt to partly control for omitted factors, we include cohort year dummy variables (whose coefficients are not reported) to account for yearly fixed effects. Since many of the return intervals overlap, they are subject to common (omitted) factors, and thus the heteroskedasticity-corrected t-statistics may still overstate the significance levels.

In all specifications, the coefficients on gross proceeds and book-to-market are insignificantly different from zero. The coefficient on age is always significantly negative. Older firms tend to exhibit systematically worse long-term performance relative to matched firms. The first and simplest specification suggests that venture capital-backed issues, taken as a whole and controlling for other factors, perform neither worse nor better than other IPOs. The coefficient estimate is both economically and statistically insignificant. Although the coefficient on direct bank invested IPOs is much larger and indicates $7.8 \%$ better performance than other IPOs, it also is not statistically significant (t-statistic of 1.45).

In regression (3) with the four venture-capital dummies separated by institutional affiliation, we find a positive coefficient on one of the four variables that is marginally significant $(\mathrm{t}=1.64)$. Venture capital-backed firms where the lead venture capitalist is either foreign or independent exhibit better performance relative to a matched sample than do other IPOs: 27 percent better over three years. Other forms of venture backing, however, do not appear to relate to significant differences in long-term performance relative to other IPOs.

The coefficients from regressions (4) and (5) indicate that no special distinction can be made among securities company-affiliated venture capital-backed IPOs in which the parent also is the managing underwriter of the IPO, and those in which it is not. The coefficients are individually insignificant, and F-tests indicate that the negative coefficients for the indicator variables for the two types of securities firm-affiliated venture capital are not significantly different from each other.

The results from the remaining regressions are also negative. Regression (6) indicates that the insignificance of bank venture backing to long-term performance is independent of the keiretsu affiliation of the bank. Regression (5) confirms that direct bank investment is not 
associated with changes in long-term performance, and regression 6 indicates that the insignificance of bank direct investment is independent of whether the bank is a keiretsu bank.

\subsection{Determinants of Underpricing}

As mentioned in the introduction, evidence from the U.S. using IPOs from the 1980s is that venture capital-backed IPOs are underpriced to a lesser extent than non-venture capitalbacked IPOs. Two of the major studies are summarized in Table 8. While the study of Barry, Muscarella, Peavy, and Vestuypens (1990) found no significant difference, based on a t-test of differences of means, Megginson and Weiss (1991) found in multiple regression analysis that venture capital-backed IPOs had significantly less underpricing than a matched sample of non venture capital-backed IPOs. This has been interpreted as consistent with venture capitalists certifying IPOs, and a reduction in information asymmetry between inside and outside investors.

In the third panel of Table 8, we report the results from U.S. IPOs over the same time period -- 1989-1995 -- as our sample of Japanese IPOs. In sharp contrast to the U.S. evidence from the 1980s, venture capital-backed IPOs have been more underpriced than non venture capital-backed IPOs. The average initial return on venture capital-backed IPOs is $14.7 \%$, compared to an average of $11.3 \%$ for other IPOs. The association of venture capital backing with greater initial returns stands up in unreported regressions that control for some of the other crosssectional determinants of short-run underpricing, including six industry dummy variables. Thus, the relation of U.S. venture-capital backing to IPO initial returns appears to have shifted over time.

We report the detailed results for our sample of Japanese IPOs from April 1989December 1995 in Table 9. The table reports six specifications of the underpricing regressions. The resulting adjusted- $\mathrm{R}^{2}$ statistics round to 0.13 to 0.15 for the six specifications, at the upper end of the range of adjusted- $\mathrm{R}^{2}$ statistics of 0.07 to 0.15 for most of the studies purporting to explain cross-sectional variation in the underpricing of IPOs in the United States. In all specifications, the instrument for the subscription ratio, age, book-to-market, and gross proceeds are significantly positive. The latter three results are surprising since there is reason to expect that ex-ante uncertainty would be less for older firms and larger issues, and for firms with higher book-to-market ratios. Nonetheless, underpricing is systematically greater for these firms. As 
expected, the institutional lag variable comes in positive, though it is not statistically significant in any of the specifications. Regression (1) of Table 9 indicates that venture capital-backed issues exhibit a significant reduction in underpricing relative to other IPOs. On average, the reduction in underpricing is nearly 11 percent ( $t$-statistic -2.39). This is in contrast the U.S. pattern during the same sample period, reported in Table 8. In regression (3) with the four venture-capital dummies separated by institutional affiliation, we find a negative coefficient on all four of the variables.

In regression (4) it is apparent that all of the reduced underpricing associated with securities firm-related venture backing occurs when the securities firm is not the managing underwriter of the issue. The coefficient on the indicator variable for the managing underwriter is insignificantly different from zero, while the coefficient on the other securities firm-related venture capital variable is a highly significant -0.35 . Thus the underpricing is not reduced when the managing underwriter of the issue faces a clear conflict of interest. The differences in underpricing depending on the potential for conflict of interest contrasts sharply with the results for long-term performance.

Just as in the long-term performance regressions, the coefficient estimates of regression (6) suggests that there is no significant difference between the certification effect of bank-related venture capital (or direct bank) investment depending on whether the bank is a keiretsu bank or not. In addition, the estimates of regressions (2), (3), (4) and (5) indicate that the reduction in underpricing that might be expected from bank certification of the quality of the IPO is only associated with investment through the bank venture capital subsidiary, and not with direct bank investment. At least for this sample, bank certification through pre-IPO investment appears to be limited to their venture capital subsidiaries and does not differ by keiretsu affiliation.

\subsection{IPO Valuation.}

Finally, we investigate how institutional affiliation affects the level of the pricing of initial public offerings in Japan relative to comparable firms. As discussed in the introduction, concerns over conflict of interest should show up in the levels of price-earnings (P/E) ratios at

the time of issue. If investors are not sufficiently skeptical, and issuing firms and their financial advisors have marketing power, "hyping" the stock may result in a P/E ratio at the time of the 
offering and in the early after-market that is considerably above those of comparables.

In the first panel of Table 10, we report the mean P/E ratios for IPOs and comparable firms, as well as a t-test for pairwise differences. Venture capital-backed IPOs where the lead underwriter is also a securities firm that has a venture stake have a mean P/E ratio of 34, which is higher than the mean P/E of 29.6 for their comparables. This is consistent with the hypothesis that these IPOs are priced more aggressively when they are brought to market. However, the statistical significance of the difference is marginal $(\mathrm{t}=1.48)$. In addition, IPOs backed by this class of venture capital did not tend to perform worse than others long-term.

In the second panel of Table 10, we report the percentage of earnings forecasts for the period subsequent to the IPO that were above realized earnings. This evidence is not consistent with a conflict of interest effect. While 61 percent of the forecasted earnings of IPOs backed by securities firm-affiliated venture capital that was not the affiliate of the lead underwriter exceeded realized earnings, in the more frequently observed cases when the securities venture capital-backed firm had the parent as a lead underwriter, only 49 percent of the time did forecasted earnings exceeded realized earnings. Thus, lead underwriters did not appear to generate overly optimistic forecasts for the current accounting period for those IPOs in which it has a venture capital stake.

\section{Conclusion}

The presence of venture capital in the ownership structure of U.S. firms going public has been associated with improved long-term performance. In Japan, most of the major venture capital firms are subsidiaries of securities firms and banks. Using a sample of firms going public on the OTC during April 1989-December 1995, we document short-run underpricing and longrun negative abnormal returns that are similar to those documented in other studies using Tokyo Stock Exchange-listed IPOs. Specifically, we report average initial returns of 15.7 percent, and a three-year wealth relative of 0.85 , calculated as the ratio of the average gross return on IPOs (from the first closing market price) relative to the average gross return on a size/industry matched sample of nonissuing firms.

We find that venture capital-backed IPOs in Japan do not perform better in the long run 
than other IPOs relative to size/industry matched firms, with the exception of firms backed by foreign owned or independent venture capitalists. When venture capital holdings are broken down by their institutional affiliation, we find that firms with venture backing from securities company subsidiaries do not have excess returns that are significantly different than other IPOs. This suggests that conflicts of interest do not influence the long-term performance of initial public offerings in Japan. While there is more short-term underpricing for venture capitalbacked IPOs, once other determinants of underpricing are controlled for, venture capital-backed IPOs are actually underpriced less. This is consistent with venture capital playing a certification role in alleviating informational uncertainty about the IPO at the time of issue. Issues for which the lead underwriter is also the parent of the lead venture capitalist, however, do not show reduced initial returns. This suggests that investors in the primary market may demand more underpricing to compensate for the potential conflict of interest. Surprisingly, while the distinction between bank-related venture capital and direct bank ownership appears important in the pricing of IPOs, whether the related bank is a keiretsu bank or not does not. 


\section{Endnotes}

1. Within the bank underwritten issues of the pre-Glass-Steagall era, there was considerable heterogeneity as well. Kroszner and Rajan (1997) have found that securities underwritten by the bank that did not set up an organization structure that separated lending and underwriting, and thus had more perceived potential for conflicts of interest, were discounted relative to comparable securities underwritten by another organization.

2. In July 1995, a new special section on the OTC was created in which profit requirements were abolished and paid-in capital requirements were reduced; however, the new section has failed to attract more than a handful of listings. Another indication of the relative maturity of IPO firms in Japan is the relative paucity of technology firms listed on the OTC. For example, the market share of computer and communications firms (of total market cap of OTC firms) in September 1997 is 2.4 percent, only one-tenth the corresponding percentage for Nasdaq in December 1996 (Isoda (1997)).

3. See Shihon Shijo Kenkyukai (Committee on Capital Markets, and advisory committee for the Ministry of Finance) (1989), or Pettway and Kaneko (1996).

4. If the issue was overbid at the maximum limit price, then rationing of the bids at the first stage would occur according to strict lottery.

5. There were 88 respondents to the Nikkei survey. A more comprehensive list from late 1997 of 167 venture capital companies and their affiliation is contained in Isoda (1997). This list indicates that 80 of the companies were bank affiliated, 22 securities company-affiliated, 25 trading, leasing, or manufacturing company affiliated, 12 insurance company affiliated, 5 government affiliated, 4 foreign, and 19 independent.

6. The responsibilities of the lead underwriter are substantial. The lead underwriter has the responsibility for preparing the application documents for listing. In the case of an OTC company, it is also given the responsibility for the official investigation of the financial condition of the company.

7. This pattern has reversed in the 1990s, however. See Beatty and Welch (1996).

8. U.S. banks can still act as agents of "certification" through the provision of loans ("inside debt"). In fact, U.S. studies show that IPOs of firms with credit relationships with private lenders are less severely underpriced on average (James and Weir (1990)). In the Japanese context, the loan/no loan dichotomy is not quite as interesting, since only extremely rarely does a firm go public without having bank loans on its books. 


\section{References}

Aoki, M., 1988, Information, Incentives, and Bargaining in the Japanese Economy, Cambridge: Cambridge University Press.

Barry, C., C. Muscarella, J. Peavy, and M. R. Vetsuypens, 1990, The role of venture capital in the creation of public companies: Evidence from the going-public process, Journal of Financial Economics 27: 447-471.

Beatty, R.P. and J. R. Ritter, 1986, Investment banking, reputation, and the underpricing of initial public offerings, Journal of Financial Economics 15: 213-232.

Beatty, R.P., and I. Welch, 1996, Issuer expenses and legal liability in initial public offerings, Journal of Law and Economics 34, 545-602.

Brav, A., and P. Gompers, 1997, Myth or Reality? The long-run underperformance of initial public offerings: Evidence from venture and nonventure capital-backed companies, Journal of Finance 52: 1791-1821.

Cai, J. and K. C. J. Wei, 1997, The investment and operating performance of Japanese initial public offerings, Pacific-Basin Finance Journal 5: 389-417.

Carter, R., and S. Manaster, 1990, Initial public offerings and underwriter reputation, Journal of Finance 45: 1045-1067.

Clark, R., 1988, Venture Capital in Britain, America, and Japan, London: Croom Helm.

Dewenter, K., W. Novaes, and R. Pettway, 1997, Market timing as a motive for IPOs: Evidence from IPOs of Japanese keiretsu firms, Unpublished University of Washington working paper.

Field, L.C., 1996, Is institutional investment in initial public offerings related to the long-term performance of these firms? Working Paper, UCLA and Penn State.

Forsythe, R., R. Lundholm, and T. Reitz, 1999, Cheap talk, fraud, and adverse selection in financial markets: Some experimental findings. Review of Financial Studies 12, 481-518.

Gande, A., M. Puri, A. Saunders, and I. Walter, 1997, Bank underwriting of debt securities: Modern evidence, Review of Financial Studies 10:1175-1202.

Gompers, P., 1995, Optimal investment, monitoring, and the staging of venture capital, Journal of Finance 50: 1461-1490. 
Gompers, P., and J. Lerner, 1997, Reputation and conflict of interest in the issuance of public securities: Evidence from venture capital, Unpublished Working Paper, Harvard Business School.

Hamao, Y., and T. Hoshi, 1999, Bank underwriting of corproate bonds: Evidence from Japan after 1994, Unpublished Working Paper, University of Southern California.

Hebner, K. J., and T. Hiraki, 1993, Japanese initial public offerings, in I. Walter and T. Hiraki eds., Restructuring Japan's Financial Markets, Homewood, IL: Business One/Irwin.

Hoshi, T., A. Kashyap, and D. Scharfstein, 1990, Bank monitoring and investment: Evidence from the changing structure of Japanese corporate banking relationships, in R. G. Hubbard ed., Asymmetric Information, Corporate Finance, and Investment, Chicago: University of Chicago Press.

Isoda, T. 1997. Nihon no Venchaa Kyapitaru ga Chokumen Suru Mondaiten to sono Taisaku. Unpublished Working Paper, Nippon Investment Finance.

James, C. and P. Wier, 1990, Borrowing relationships, intermediation, and the costs of issuing public securities, Journal of Financial Economics 28:149-171.

Jenkinson, T. 1990, Initial public offerings in the United Kingdom, the United States, and Japan, Journal of the Japanese and International Economies 4: 428-449.

Kakitsuka, M., 1991, Oonaa Kaisha no Kabushiki Kokai 50 no Hiketsu, Tokyo: Gyosei.

Toyo Keizai Shimpo Sha, Quarterly, 1988-96, Kaisha Shikiho, Tokyo.

Kang, J., and R. Stulz, 1996, How Different Is Japanese Corporate Finance? An Investigation of the Information Content of New Securities Issues, Review of Financial Studies 9: 109-139.

Kato M., and Matsuno, Y., 1991, Kabushiki Kokai no Chishiki, Tokyo: Nihon Keizai Shimbun.

Kroszner, R. S., and R. Rajan, 1994, Is the Glass Steagall Act Justified? A Study of the US Experience with Universal Banking Before 1933, American Economic Review 84: 810-832.

Kroszner, R. S., and R. Rajan, 1997, Organization Structure and Credibility: Evidence from Commercial Bank Securities Activities Before the Glass-Steagall Act, Journal of Monetary Economics 39: 475-516.

La Porta, Rafael, and Florencio Lopez-de-Silanes, Andrei Shleifer, and Robert W. Vishny. 1999. Dividend Policies Around the World," NBER Working Paper No. 6594, June.

Lang, M., and R. Lundholm, 1999, Voluntary Disclosure During Equity Offerings: Reducing Information Asymmetry or Hyping the Stock? Forthcoming, Contemporary Accounting Research. 
Lerner, J., 1994, Venture Capitalists and the Decision to Go Public, Journal of Financial Economics 35: 293-316.

Lerner, J., 1995, Venture Capitalists and the Oversight of Private Firms, Journal of Finance 50: 301317.

Loughran, T., and J. R. Ritter, 1995, The New Issues Puzzle, Journal of Finance 50: 23-51.

Loughran, T. J. R. Ritter, and K. Rydqvist, 1994, Initial public offerings: International Insights, Pacific-Basin Finance Journal 2: 165-199.

Megginson, W. L. and K. Weiss, 1991, Venture Capitalist Certification in Initial public offerings, Journal of Finance 46: 879-903.

Nihon Keizai Shimbun, 1991, Nikkei Venture, June.

Nikkei Kinyu Shimbun. July 15, 1997. 96-Nendo Venchaa Kyapitaru Chosa. (Survey of Venture Capital in Fiscal-Year 1996).

Packer, F., 1996, Venture capital, bank shareholding, and IPO underpricing in Japan, in Levis, M. ed., Empirical Issues in Raising Equity Capital, Amsterdam: North-Holland.

Pettway, R. and T. Kaneko, 1996, The effects of removing price limits and introducing auctions upon short-term IPO returns: The case of Japanese IPOs, Pacific-Basin Finance Journal, 4: 241-158.

Pettway, R. and T. Kaneko, 1997, A comparison of the impacts of the partial auction system of Japanese IPOs versus the U.S. discretionary allocation system, unpublished U of Missouri working paper.

Prowse, S., 1990, Institutional investment patterns and corporate financial behavior in the United States and Japan, Journal of Financial Economics, 27: 43-66.

Puri, M., 1996, Commercial banks in investment banking: Conflict of interest or certification role?, Journal of Financial Economics 40: 373-401.

Ritter, J. R., 1991, The long-run performance of initial public offerings, Journal of Finance 46: 327.

Shimon Shijo Kenkyukai, 1989, Kabushiki kokai no arikata ni tsuite (On Revisions of the Methods to Go Public).

Sutton, D. P., Benedetto, M.W., 1990, Initial Public Offerings, Chicago: Probus Publishing Company. 
Venture Enterprise Center, Ministry of International Trade and Industry. 1991. Promotion of Venture Businesses and the Venture Capital Industry, Tokyo.

Venture Enterprise Center, Ministry of International Trade and Industry. 1997. Venchaa Kyapitaru Toshi Jokyo Chosa Yoshi (Summary of the March 1996 Survey of the Condition of Japanese Venture Capital), Tokyo. 
TABLE 1

Average Initial Return and Long-term Performance of Initial Public Offerings on the OTC: April 1989 - December 1995.

\begin{tabular}{|c|c|c|c|c|c|c|c|}
\hline Year & $\begin{array}{l}\text { Sample } \\
\text { Size }\end{array}$ & $\begin{array}{l}\text { Gross } \\
\text { Proceeds } \\
\text { (mm yen) } \\
\text { (Mean) }\end{array}$ & $\begin{array}{l}\text { Initial } \\
\text { Return } \\
\text { (Mean) }\end{array}$ & $\begin{array}{l}\text { 3-Year } \\
\text { Holding } \\
\text { Period } \\
\text { Return } \\
\text { (Mean) }\end{array}$ & $\begin{array}{l}\text { 3-Year } \\
\text { Comparables } \\
\text { HPR } \\
\text { (Mean) }\end{array}$ & $\begin{array}{l}\text { 3-Year } \\
\text { Excess } \\
\text { Return } \\
\text { (Mean) }\end{array}$ & $\begin{array}{c}\text { 3-Year } \\
\text { Wealth } \\
\text { Relative } \\
\text { (Ratio of Means) }\end{array}$ \\
\hline 1989 & 43 & $\begin{array}{l}6151.4 \\
(8739.6)\end{array}$ & $\begin{array}{c}7.7 \% \\
(10.5 \%)\end{array}$ & $\begin{array}{l}-46.0 \% \\
(38.5 \%)\end{array}$ & $\begin{array}{l}-46.2 \% \\
(19.4 \%)\end{array}$ & $\begin{array}{c}0.2 \% \\
(37.8 \%)\end{array}$ & 1.005 \\
\hline 1990 & 82 & $\begin{array}{c}5449.6 \\
(5283.1)\end{array}$ & $\begin{array}{c}17.6 \% \\
(31.6 \%)\end{array}$ & $\begin{array}{l}-51.8 \% \\
(33.6 \%)\end{array}$ & $\begin{array}{l}-31.5 \% \\
(24.0 \%)\end{array}$ & $\begin{array}{l}-20.3 \% \\
(33.8 \%)\end{array}$ & 0.704 \\
\hline 1991 & 81 & $\begin{array}{r}5573.1 \\
(9538.4)\end{array}$ & $\begin{array}{c}28.5 \% \\
(52.1 \%)\end{array}$ & $\begin{array}{l}-21.4 \% \\
(58.9 \%)\end{array}$ & $\begin{array}{c}-22.9 \% \\
(19.4 \%)\end{array}$ & $\begin{array}{r}1.5 \% \\
(59.2 \%)\end{array}$ & 1.020 \\
\hline 1992 & 9 & $\begin{array}{c}3255.5 \\
(2049.4)\end{array}$ & $\begin{array}{c}15.8 \% \\
(23.5 \%)\end{array}$ & $\begin{array}{l}-39.6 \% \\
(46.8 \%)\end{array}$ & $\begin{array}{r}-5.7 \% \\
(7.0 \%)\end{array}$ & $\begin{array}{c}-33.9 \% \\
(50.9 \%)\end{array}$ & 0.641 \\
\hline 1993 & 44 & $\begin{array}{l}6159.2 \\
(10622.3)\end{array}$ & $\begin{array}{c}12.8 \% \\
(14.3 \%)\end{array}$ & $\begin{array}{l}-13.3 \% \\
(54.0 \%)\end{array}$ & $\begin{array}{c}-8.8 \% \\
(18.4 \%)\end{array}$ & $\begin{array}{c}-4.5 \% \\
(56.1 \%)\end{array}$ & 0.951 \\
\hline 1994 & 96 & $\begin{array}{c}4802.9 \\
(5613.7)\end{array}$ & $\begin{array}{c}11.1 \% \\
(13.1 \%)\end{array}$ & $\begin{array}{l}-51.4 \% \\
(39.2 \%)\end{array}$ & $\begin{array}{l}-33.0 \% \\
(20.8 \%)\end{array}$ & $\begin{array}{l}-18.4 \% \\
(42.2 \%)\end{array}$ & 0.726 \\
\hline 1995 & 101 & $\begin{array}{c}2795.7 \\
(3221.1)\end{array}$ & $\begin{array}{c}12.8 \% \\
(16.0 \%)\end{array}$ & NA & NA & NA & NA \\
\hline 8904-9203 & 206 & $\begin{array}{c}5644.7 \\
(7890.0)\end{array}$ & $\begin{array}{c}19.8 \% \\
(39.2 \%)\end{array}$ & $\begin{array}{l}-39.2 \% \\
(48.0 \%)\end{array}$ & $\begin{array}{l}-31.2 \% \\
(22.9 \%)\end{array}$ & $\begin{array}{c}-7.4 \% \\
(47.2 \%)\end{array}$ & 0.892 \\
\hline $9204-9412$ & 149 & $\begin{array}{c}5110.0 \\
(7337.3)\end{array}$ & $\begin{array}{c}11.9 \% \\
(14.2 \%)\end{array}$ & $\begin{array}{l}-39.4 \% \\
(47.4 \%)\end{array}$ & $\begin{array}{c}-24.2 \% \\
(22.8 \%)\end{array}$ & $\begin{array}{r}-15.2 \% \\
(47.5 \%)\end{array}$ & 0.799 \\
\hline 9204-9512 & 250 & $\begin{array}{c}4175.0 \\
(6120.5)\end{array}$ & $\begin{array}{c}12.3 \% \\
(14.9 \%)\end{array}$ & NA & NA & NA & NA \\
\hline $\begin{array}{l}\text { Total from } \\
1989-95\end{array}$ & 456 & $\begin{array}{c}4838.9 \\
(7006\end{array}$ & $\begin{array}{l}15.7 \% \\
(28 . \%)\end{array}$ & NA & NA & NA & NA \\
\hline $\begin{array}{c}\text { Total from } \\
1989-94\end{array}$ & 355 & $\begin{array}{c}5420.2 \\
(7656.9)\end{array}$ & $\begin{array}{c}16.5 \% \\
(31.5 \%)\end{array}$ & $\begin{array}{l}-38.9 \% \\
(47.7 \%)\end{array}$ & $\begin{array}{l}-28.2 \% \\
(23.1 \%)\end{array}$ & $\begin{array}{l}-10.7 \% \\
(47.4 \%)\end{array}$ & 0.851 \\
\hline
\end{tabular}

Note: The sample includes only those IPO firms for which a matching sample of at least one non-IPO firm in the same industry and size decile could be obtained. Gross proceeds are the value of shares sold in the pre-issue auction and the IPO at the offer price. The initial return is the percentage difference between the first closing market price and the offer price. The excess three year return is the three year buy-and-hold return minus the three-year buy-and-hold return over the same period for a portfolio (composed of at least one firm) of comparable non-IPO firms matched by size and industry. The buy-and-hold return for the IPO starts with the closing market price on the first day of trading. The wealth relatives are defined as one plus the average three-year buy-and-hold return divided by one plus the average three-year return for the comparable non-IPO firms. For example, the 1989 wealth relative of 1.005 is calculated as $0.540 / 0.538$. The average yen-dollar exchange rate was about 120 during this period, so the mean of gross proceeds is about $\$ 40$ million. Firms that went public and subsequently delisted are included until the date of delisting. The numbers in parentheses are standard deviations. 
TABLE 2

Characteristics of Venture-Backed versus Other IPOs: April 1989 - December 1995
Venture-Backed IPOs
(210 Firms)
Other IPOs
(246 Firms)

\begin{tabular}{|c|c|c|c|c|}
\hline & Mean & Median & Mean & Median \\
\hline $\begin{array}{l}\text { Gross Proceeds } \\
\text { (mm yen) }\end{array}$ & $\begin{array}{c}4192.4^{*} \\
(5735.6)\end{array}$ & $2632.0^{\star \star \star}$ & $\begin{array}{c}5390.8 \\
(7901.3)\end{array}$ & 3350.3 \\
\hline Book-to-Market & $\begin{array}{c}0.41 \\
(0.64)\end{array}$ & 0.28 & $\begin{array}{c}0.36 \\
(0.54)\end{array}$ & 0.27 \\
\hline Age (Years) & $\begin{array}{c}33.2^{\star \star \star} \\
(13.0)\end{array}$ & $32.0^{\star \star \star}$ & $\begin{array}{l}36.78 \\
(13.3)\end{array}$ & 36.0 \\
\hline Initial Return & $\begin{array}{l}19.2 \%{ }^{\star \star *} \\
(32.9 \%)\end{array}$ & $8.0 \%$ & $\begin{array}{c}12.7 \% \\
(24.5 \%)\end{array}$ & $5.8 \%$ \\
\hline $\begin{array}{l}\text { 3-Year Holding } \\
\text { Period Return } \\
\text { (IPO) }\end{array}$ & $\begin{array}{l}-39.4 \% \\
(50.0 \%)\end{array}$ & $-54.4 \%$ & $\begin{array}{l}-38.5 \% \\
(45.7 \%)\end{array}$ & $-52.0 \%$ \\
\hline $\begin{array}{l}\text { 3-Year Holding Period } \\
\text { Return } \\
\text { (Comparables) }\end{array}$ & $\begin{array}{l}-29.8 \% \\
(23.2 \%)\end{array}$ & $-32.8 \%$ & $\begin{array}{l}-27.0 \% \\
(23.0 \%)\end{array}$ & $-28.2 \%$ \\
\hline $\begin{array}{l}\text { 3-Year Excess } \\
\text { Return }\end{array}$ & $\begin{array}{c}-9.6 \% \\
(50.8 \%)\end{array}$ & $-20.8 \%$ & $\begin{array}{l}-11.6 \% \\
(44.5 \%)\end{array}$ & $-19.2 \%$ \\
\hline Wealth Relative & 0.863 & & 0.842 & \\
\hline
\end{tabular}

Venture Backed IPOs are defined as those that had a venture capitalist as a top ten shareholder immediately prior to the IPO. The Book-to-market ratio is calculated using post-offering book value of equity and offer price. Age is time between the establishment of the company and its IPO. Gross Proceeds, underpricing, excess returns, and wealth relatives calculated as in Table 1. Mean and median 3-year holding period return, excess return, and wealth relatives are calculated only for IPOs that took place prior to $12 / 31 / 94$. $\mathrm{A}^{*},{ }^{* *},{ }^{* * *}$ indicates that mean (or median) for the venture-backed sample is significantly different than that for the non-venture-backed sample at the $10 \%, 5 \%$ and $1 \%$ level. (t-tests for difference in means assume independence and normality. Wilcoxon rank-sum testsare used for the differences in medians). Numbers in parentheses are standard deviations. 
TABLE 3

Venture Capital Investment in Firms Going Public on the OTC, April 1989-December 1995

\begin{tabular}{|c|c|c|c|c|}
\hline No. of & $\begin{array}{l}\text { Number of } \\
\text { Firms for } \\
\text { Which this } \\
\text { Type is a } \\
\text { Secondary }\end{array}$ & $\begin{array}{l}\text { Mean Number } \\
\text { Of Venture Capitalists } \\
\text { as Major Shareholders }\end{array}$ & $\begin{array}{l}\text { Mean \% of Equity } \\
\text { Held by Lead } \\
\text { Venture Capitalist }\end{array}$ & $\begin{array}{l}\text { Mean \% of Equity } \\
\text { Held by Venture } \\
\text { Capitalists Which } \\
\text { Are Major Shareholders }\end{array}$ \\
\hline Firms & Ven. Capitalist & Pre-IPO Post-IPO & Pre-IPO Post-IPO & Pre-IPO Post-IPO \\
\hline
\end{tabular}

Firms with Venture

Capitalist as Major

Shareholder

Prior to IPO

210

1.51

1.39

$5.92 \% \quad 4.07 \%$

$7.50 \% \quad 4.92 \%$

Categorized by Affiliation of Lead Venture Capitalist:

\section{Securities \\ firm subsidiary}

$$
99
$$

independent
32

47

24

1

27
1.53

1.45

1.33

1.94

1.52

1.40

1.31

1.22
16
7

7

Pre-IPO Post-IPO

\author{
sts Which \\ Pre-IPO Post-IPO
}

\footnotetext{
Post-IPO equity holdings are from Toyo Keizai Shimpo Sha, Kaisha Shikiho, measured at the end of the first accounting cycle that is at least six months after the offer date. Major shareholders are defined as being one of the top ten shareholders. A venture capitalist is counted as the lead if it is among the top ten shareholders prior to the IPO and it has more shares than any other venture capitalist. All other venture capitalists among the firm's top ten shareholders are classified as secondary venture capitalists. SBIC stands for small business investment corporations, semi-governmental institutions set up in Nagoya, Osaka, and Tokyo with capital contributed by local governments and local financial institutions.
} 
TABLE 4

The Relationship Between Venture Capital Participation and the Position of Lead Underwriter: IPOs on the OTC, April 1989- December 1995

$\begin{array}{llll} & \begin{array}{l}\text { Number of IPOs } \\ \text { in Which Venture } \\ \text { Capital Subsidiary } \\ \text { was the Lead } \\ \text { Venture } \\ \text { Capitalist (A) }\end{array} & \begin{array}{l}\text { Number of (A) } \\ \text { in Which the } \\ \text { Securities Firm } \\ \text { was the Lead } \\ \text { Firm }\end{array} & \begin{array}{l}\text { Underwriter } \\ \text { (Percent) }\end{array} \\ \text { Nomura } & 59 & 49 & 83.1 \% \\ \text { Daiwa } & 9 & 8 & 88.9 \% \\ \text { Nikko } & 8 & 8 & 100.0 \% \\ \text { Yamaichi } & 7 & 7 & 100.0 \% \\ \text { Sanyo } & 5 & 0 & 0.0 \% \\ \text { Maruman } & 3 & 0 & 0.0 \% \\ \text { Wako } & 2 & 1 & 50.0 \% \\ \text { Marusan } & 2 & 1 & 50.0 \% \\ \text { Okasan } & 2 & 0 & 0.0 \% \\ \text { Kankaku } & 1 & 1 & 100.0 \% \\ \text { Shinnippon } & 1 & 76 & 100.0 \% \\ \text { TOTAL } & 99 & & 76.8 \%\end{array}$

Note: Lead venture capitalist is defined as in Table 3. 
TABLE 5

Direct Bank Investment in Firms Going Public

\begin{tabular}{|c|c|c|c|}
\hline & & $\begin{array}{l}\text { Mean \% of Equity } \\
\text { Held by Lead } \\
\text { Bank Shareholder }\end{array}$ & $\begin{array}{l}\text { Mean \% of Equity Held } \\
\text { by Banks Which Are } \\
\text { Maior Shareholders }\end{array}$ \\
\hline & & Post-IPO & IPO \\
\hline
\end{tabular}

Firms with Bank as Major Shareholder Prior to IPO 363

$$
2.16
$$

2.77

2.89

3.29

5.22

7.10

(of which group bank is lead bank shareholder)

Sources: Kaisha Shikiho, quarterly issues, 1989-1996. The sample is 456 IPOs from 1989-1995. 
TABLE 6.

Mean Sample Characteristics According to Institutional Affiliation of Lead Venture Capitalist or Identity of Direct Bank Investor

\begin{tabular}{|c|c|c|c|c|c|c|c|c|}
\hline $\begin{array}{l}\text { No. of } \\
\text { Firms }\end{array}$ & $\begin{array}{l}\text { Gross } \\
\text { Proceeds } \\
\text { (mm yen) }\end{array}$ & Age & $\begin{array}{c}\text { Book-to } \\
\text { Market }\end{array}$ & $\begin{array}{l}\text { Initial } \\
\text { Return }\end{array}$ & $\begin{array}{l}\text { Mean of } \\
\text { 3-year } \\
\text { HPR }\end{array}$ & $\begin{array}{c}\text { Mean of } \\
\text { 3-year } \\
\text { HPR }\end{array}$ & $\begin{array}{l}\text { 3-Year } \\
\text { Excess } \\
\text { Return }\end{array}$ & $\begin{array}{l}\text { 3-Year } \\
\text { Wealth } \\
\text { Relative }\end{array}$ \\
\hline
\end{tabular}

\begin{tabular}{|c|c|c|c|c|c|c|c|c|c|}
\hline \multirow{2}{*}{$\begin{array}{l}\text { Venture-Backed IPOs } \\
\qquad \text { (Securities Firm } \\
\text { Affiliated) }\end{array}$} & 161 & $\begin{array}{c}4575 \\
(6104)\end{array}$ & $\begin{array}{c}33.0 \\
(12.6)\end{array}$ & $\begin{array}{l}0.38 \\
(0.68)\end{array}$ & $\begin{array}{l}20.0 \% \\
(36.1 \%)\end{array}$ & $\begin{array}{l}-39.4 \% \\
(50.0 \%)\end{array}$ & $\begin{array}{l}-29.8 \% \\
(23.2 \%)\end{array}$ & $-9.6 \%$ & 0.863 \\
\hline & 76 & $\begin{array}{l}4623 \\
(6861)\end{array}$ & $\begin{array}{l}31.9 \\
(11.3)\end{array}$ & $\begin{array}{l}0.30 \\
(0.34)\end{array}$ & $\begin{array}{l}20.6 \% \\
(38.2 \%)\end{array}$ & $\begin{array}{l}-41.2 \% \\
(56.1 \%)\end{array}$ & $\begin{array}{c}-33.1 \% \\
(19.7 \%)\end{array}$ & $-8.1 \%$ & 0.879 \\
\hline (Lead Underwriter) & 57 & $\begin{array}{c}5315 \\
(7777)\end{array}$ & $\begin{array}{c}32.2 \\
(11.3)\end{array}$ & $\begin{array}{l}0.32 \\
(0.39)\end{array}$ & $\begin{array}{l}19.5 \% \\
(33.5 \%)\end{array}$ & $\begin{array}{l}-39.1 \% \\
(59.3 \%)\end{array}$ & $\begin{array}{r}-30.27 \% \\
(19.9 \%)\end{array}$ & $-8.8 \%$ & 0.874 \\
\hline (Bank Affiliated) & 54 & $\begin{array}{r}5010 \\
(6134)\end{array}$ & $\begin{array}{l}31.6 \\
(13.5)\end{array}$ & $\begin{array}{l}0.48 \\
(0.94)\end{array}$ & $\begin{array}{l}17.9 \% \\
(33.8 \%)\end{array}$ & $\begin{array}{l}-43.2 \% \\
(41.3 \%)\end{array}$ & $\begin{array}{l}-27.0 \% \\
(25.5 \%)\end{array}$ & $-16.2 \%$ & 0.778 \\
\hline (Keiretsu Bank) & 17 & $\begin{array}{r}4648 \\
(4282)\end{array}$ & $\begin{array}{l}33.4 \\
(16.0)\end{array}$ & $\begin{array}{l}0.65 \\
(1.40)\end{array}$ & $\begin{array}{l}10.2 \% \\
(14.0 \%)\end{array}$ & $\begin{array}{l}-38.8 \% \\
(44.7 \%)\end{array}$ & $\begin{array}{l}-25.0 \% \\
(23.5 \%)\end{array}$ & $-13.8 \%$ & 0.816 \\
\hline$(\mathrm{SBIC})$ & 18 & $\begin{array}{r}3320 \\
(1662)\end{array}$ & $\begin{array}{l}43.2 \\
(10.9)\end{array}$ & $\begin{array}{l}0.51 \\
(0.98)\end{array}$ & $\begin{array}{c}18.1 \% \\
(23.3 \%)\end{array}$ & $\begin{array}{l}-39.0 \% \\
(33.6 \%)\end{array}$ & $\begin{array}{l}-22.0 \% \\
(30.5 \%)\end{array}$ & $-17.0 \%$ & 0.782 \\
\hline (Foreign or other) & 13 & $\begin{array}{c}4225 \\
(5404)\end{array}$ & $\begin{array}{l}30.7 \\
(13.7)\end{array}$ & $\begin{array}{l}0.26 \\
(0.20)\end{array}$ & $\begin{array}{c}27.2 \% \\
(48.1 \%)\end{array}$ & $\begin{array}{c}-13.6 \% \\
(62.0 \%)\end{array}$ & $\begin{array}{l}-32.4 \% \\
(19.0 \%)\end{array}$ & $18.8 \%$ & 1.278 \\
\hline Direct Bank Investment & 188 & $\begin{array}{c}5624 \\
(7236)\end{array}$ & $\begin{array}{l}35.5 \\
(13.0)\end{array}$ & $\begin{array}{l}0.31 \\
(0.40)\end{array}$ & $\begin{array}{c}15.4 \% \\
(30.3 \%)\end{array}$ & $\begin{array}{r}-37.1 \% \\
(50.0 \%)\end{array}$ & $\begin{array}{l}-29.0 \% \\
(22.6 \%)\end{array}$ & $-8.1 \%$ & 0.886 \\
\hline (Keiretsu) & 99 & $\begin{array}{l}6667 \\
(8527)\end{array}$ & $\begin{array}{l}35.4 \\
(12.4)\end{array}$ & $\begin{array}{c}0.28 \\
(0.31)\end{array}$ & $\begin{array}{l}12.4 \% \\
(21.8 \%)\end{array}$ & $\begin{array}{l}-41.4 \% \\
(43.7 \%)\end{array}$ & $\begin{array}{l}-30.1 \% \\
(23.0 \%)\end{array}$ & $-11.2 \%$ & 0.838 \\
\hline
\end{tabular}

Note: Variables defined as in Tables 1-3. IPOs that occurred in 1995 are not used in the calculation of this table. Numbers in parentheses are standard deviations. 
TABLE 7.

Long-term Performance Regression with Cohort Year Fixed Effects (standard error in parentheses)

\begin{tabular}{|c|c|c|c|c|c|c|}
\hline & Model 1 & Model 2 & Model 3 & Model 4 & Model 5 & Model 6 \\
\hline intercept & $\begin{array}{l}0.450 \\
(1.41)\end{array}$ & $\begin{array}{c}0.394 \\
(1.22)\end{array}$ & $\begin{array}{c}0.431 \\
(1.34)\end{array}$ & $\begin{array}{l}0.429 \\
(1.33)\end{array}$ & $\begin{array}{l}0.355 \\
(1.09)\end{array}$ & $\begin{array}{l}0.338 \\
(1.04)\end{array}$ \\
\hline $\ln ($ age $)$ & $\begin{array}{l}-0.171 \\
(-2.32)\end{array}$ & $\begin{array}{l}-0.169 \\
(-2.30)\end{array}$ & $\begin{array}{l}-0.167 \\
(-2.26)\end{array}$ & $\begin{array}{l}-0.167 \\
(-2.26)\end{array}$ & $\begin{array}{l}-0.161 \\
(-2.16)\end{array}$ & $\begin{array}{l}-0.160 \\
(-2.15)\end{array}$ \\
\hline $\ln ($ proceeds $)$ & $\begin{array}{l}-0.016 \\
(-0.51)\end{array}$ & $\begin{array}{l}-0.018 \\
(-0.60)\end{array}$ & $\begin{array}{l}-0.011 \\
(-0.34)\end{array}$ & $\begin{array}{l}-0.010 \\
(-0.31)\end{array}$ & $\begin{array}{l}-0.014 \\
(-0.43)\end{array}$ & $\begin{array}{l}-0.009 \\
(-0.43)\end{array}$ \\
\hline $\ln (b / m)$ & $\begin{array}{l}-0.020 \\
(-0.51)\end{array}$ & $\begin{array}{l}-0.021 \\
(-0.54)\end{array}$ & $\begin{array}{l}-0.009 \\
(-0.23)\end{array}$ & $\begin{array}{l}-0.008 \\
(-0.22)\end{array}$ & $\begin{array}{l}-0.010 \\
(-0.28)\end{array}$ & $\begin{array}{l}-0.012 \\
(-0.30)\end{array}$ \\
\hline VC-Backed & $\begin{array}{l}0.004 \\
(0.07)\end{array}$ & $\begin{array}{l}0.035 \\
(0.62)\end{array}$ & & & & \\
\hline BankDirect & & $\begin{array}{l}0.078 \\
(1.45)\end{array}$ & & & $\begin{array}{l}0.072 \\
(1.34)\end{array}$ & \\
\hline SecV & & & $\begin{array}{l}0.007 \\
(0.10)\end{array}$ & & & $\begin{array}{l}0.036 \\
(0.50)\end{array}$ \\
\hline BankV & & & $\begin{array}{l}-0.050 \\
(-0.71)\end{array}$ & $\begin{array}{l}-0.051 \\
(-0.71)\end{array}$ & $\begin{array}{l}0.007 \\
(0.09)\end{array}$ & \\
\hline SBIC & & & $\begin{array}{l}-0.039 \\
(-0.40)\end{array}$ & $\begin{array}{l}-0.039 \\
(-0.40)\end{array}$ & $\begin{array}{l}-0.046 \\
(-0.47)\end{array}$ & $\begin{array}{l}-0.040 \\
(-0.39)\end{array}$ \\
\hline OtherV & & & $\begin{array}{r}0.268 \\
(1.64) \\
\end{array}$ & $\begin{array}{l}0.268 \\
(1.63) \\
\end{array}$ & $\begin{array}{l}0.294 \\
(1.80) \\
\end{array}$ & $\begin{array}{l}0.289 \\
(1.76) \\
\end{array}$ \\
\hline SecVleadU & & & & $\begin{array}{l}0.002 \\
(0.02) \\
\end{array}$ & $\begin{array}{l}0.028 \\
(0.32) \\
\end{array}$ & \\
\hline SecVnonleadU & & & & $\begin{array}{l}0.022 \\
(0.21) \\
\end{array}$ & $\begin{array}{l}0.042 \\
(0.41)\end{array}$ & \\
\hline BankVKei & & & & & & $\begin{array}{l}0.051 \\
(0.50)\end{array}$ \\
\hline BankVNonK & & & & & & $\begin{array}{l}-0.010 \\
(0.11)\end{array}$ \\
\hline BankDirectK & & & & & & $\begin{array}{l}0.054 \\
(0.88)\end{array}$ \\
\hline BankDirectnonK & & & & & & $\begin{array}{c}0.10 \\
(1.45)\end{array}$ \\
\hline Adjusted R2 & 0.0436 & 0.0465 & 0.0491 & 0.0464 & 0.0485 & 0.0478 \\
\hline Prob $>F$ & 0.0035 & 0.0030 & 0.0034 & 0.0034 & 0.0053 & 0.0067 \\
\hline No. of Firms & 355 & 355 & 355 & 355 & 355 & 355 \\
\hline
\end{tabular}


Note: The table reports regression coefficients of 3-year excess return (over matched firms) of IPOs on various independent variables. A return of $-40 \%$ is measured as -.40 , and measured from the closing market price at the end of the first day of trading. Ln(age) is defined as the log of age of the IPO firm plus 1. Ln(proceeds) is defined as the log of gross proceeds of the IPO. $\mathrm{Ln}(\mathrm{b} / \mathrm{m})$ is defined as the log of book equity to market value equity on the first trading date. VC-Backed is a dummy that takes on the value one when venture capitalist is among the top 10 shareholders in the IPO. $\mathrm{SecV}$ is a dummy that takes on the value one when a securities venture capital is the lead investor. SecVleadU is a dummy that takes on the value one when $\mathrm{SecV}=1$ and the securities firm that is the parent of the lead venture capital company is also the lead underwriter, otherwise SecVnonleadU (SecVleadU + SecVnonleadU $=S e c V$ ). Bank V is a dummy that takes on the value one when a bank affiliated venture investor is the lead investor. BankVKeiretsu is a dummy that takes on the value one when a parent of affiliated venture capitalist is one of keiretsu banks, otherwise BankVnonK=1 (BankVKeiretsu + BankVnonK = BankV). SBIC is a dummy that takes on the value one when a SBIC is a lead shareholder. OtherV is a dummy that takes on the value one when foreign investor or independent venture capitalist is a lead shareholder. BankDirect is a dummy that takes on the value one if a bank directly invests in the IPO firm and leads other venture capitalists and direct financial institution holdings, but excluding cases when BankV = 1 . BankDirectK is a dummy that takes on the vlaue one when IPO's lead shareholder belongs to keiretsu bank group, otherwise BankDirectnonK = 1(BankDirectK + BankKirectnonK = BankDirect). The sample period is 1989-1994, with returns measured through December 31, 1997. Cohort year dummy variables (not reported) are used for 1989-1993. Heteroskedasicity consistent T-statistics are reported in parentheses. 
TABLE 8

Comparing the Findings Relating the Existence of Venture Capital Backing to Initial Returns of IPOs in the U.S.

\begin{tabular}{|c|c|c|c|c|}
\hline & $\mathbf{N}$ & $\begin{array}{c}\text { Mean } \\
\text { (median) } \\
\text { Initial Return, } \\
\%\end{array}$ & $\begin{array}{l}\text { Mean } \\
\text { (Median) } \\
\text { Proceeds, } \\
\text { million }\end{array}$ & Empirical Finding \\
\hline \multicolumn{5}{|c|}{ Panel A: Barry, Muscarella, Peavy, and Vetsuypens (1990, Table 4, Panels C/D) Sampl } \\
\hline Non VC-backed IPOs & 991 & $\begin{array}{l}7.7 \% \\
(1.5 \%)\end{array}$ & $\begin{array}{l}\$ 28.3 \\
(\$ 10.4)\end{array}$ & \multirow{2}{*}{$\begin{array}{l}\text { Venture capital-backed IPOs } \\
\text { do not have significantly } \\
\text { different initial returns. }\end{array}$} \\
\hline VC-backed IPOs & 220 & $\begin{array}{l}6.9 \% \\
(2.0 \%)\end{array}$ & $\begin{array}{c}\$ 22.9 \\
(\$ 16.8)\end{array}$ & \\
\hline \multicolumn{5}{|c|}{ Panel B: Megginson and Weiss (1991, Table 6, Panel B) Sample period: 1983-1987 } \\
\hline Non VC-backed IPOs & 320 & $\begin{array}{l}7.6 \% \\
(1.6 \%)\end{array}$ & $\begin{array}{l}\$ 13.2 \\
(\$ 9.2)\end{array}$ & \multirow[t]{2}{*}{$\begin{array}{l}\text { Venture capital-backed IPOs } \\
\text { have lower initial returns. }\end{array}$} \\
\hline VC-backed IPOs & 320 & $\begin{array}{l}7.1 \% \\
(2.5 \%)\end{array}$ & $\begin{array}{c}\$ 19.7 \\
(\$ 13.2)\end{array}$ & \\
\hline \multicolumn{5}{|c|}{ Panel C: Securities Data Co. (this paper, U.S. Data) Sample period: April 1989-Dec. 1995} \\
\hline Non VC-backed IPOs & 1228 & $\begin{array}{l}11.3 \% \\
(5.6 \%)\end{array}$ & $\begin{array}{c}\$ 66.1 \\
(\$ 28.5)\end{array}$ & \multirow{2}{*}{$\begin{array}{l}\text { Venture capital-backed IPOs } \\
\text { have higher initial returns. }\end{array}$} \\
\hline VC-backed IPOs & 937 & $\begin{array}{l}14.7 \% \\
(7.1 \%)\end{array}$ & $\begin{array}{c}\$ 41.2 \\
(\$ 28.6)\end{array}$ & \\
\hline
\end{tabular}

The empirical finding of Barry et al (Panel A) was based on a t-test of difference in means; the empirical findings of last two panels were based on multiple regressions in which the initial return is the dependent variable and the existence of venture capital backing is one of the independent variables. The sample of Megginson and Weiss (Panel B) involved a procedure that matched venture capital-backed firms with non venture capital-backed firms based on size and industry. Data for Panel C are from Securities Data Co. That panel's sample is composed of firm commitment IPOs with an offer price of at least $\$ 5.00$ and proceeds of at least $\$ 5$ million. Closed-end funds, ADRs, and unit offerings are excluded. Initial returns are the percentage price change from the offer price to the first closing market price. Proceeds are calculated on a global basis assuming no overallotment options are exercised. 
TABLE 9

Initial Return Regressions

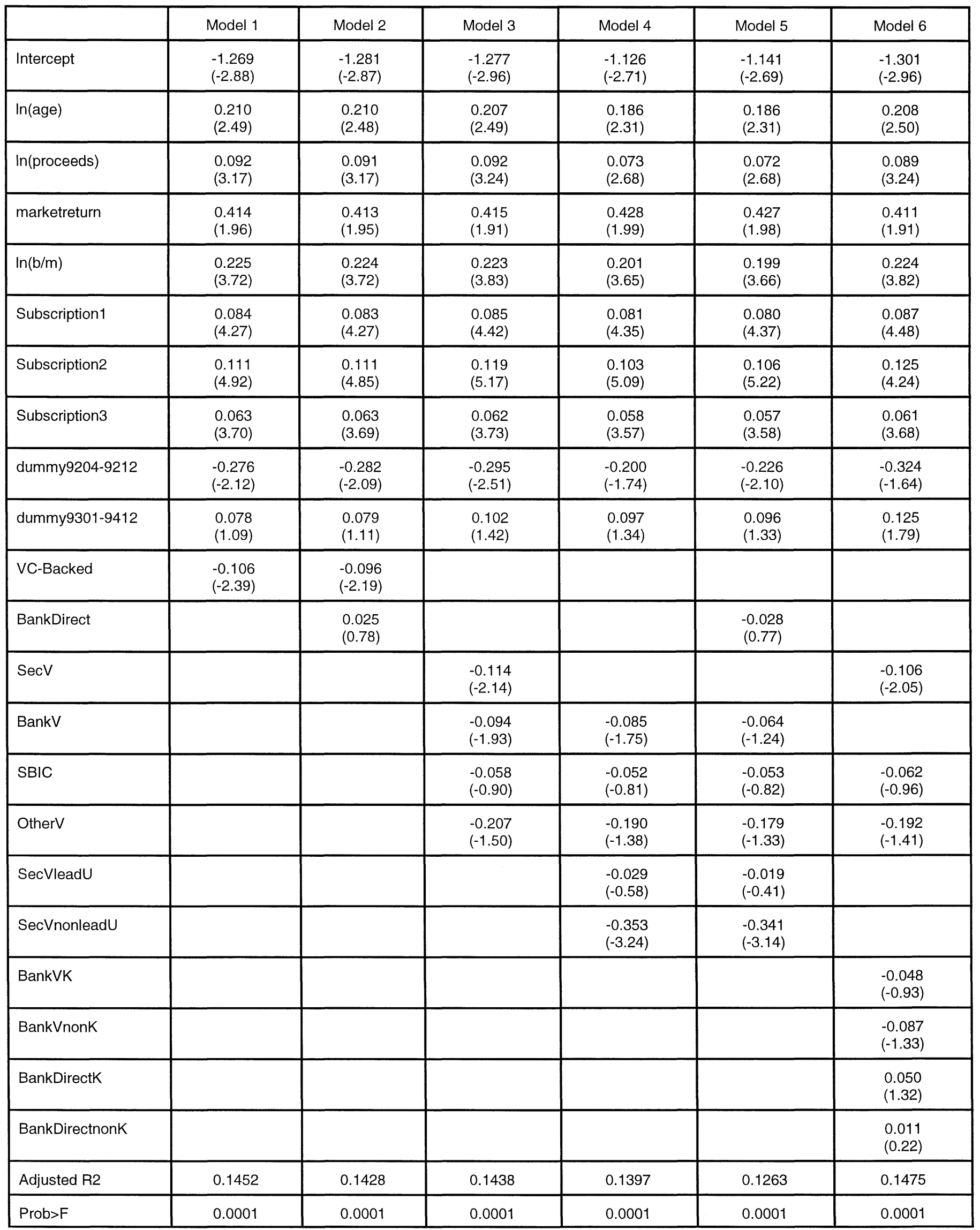




\begin{tabular}{|l|l|l|l|l|l|l|}
\hline Number of Firms & 355 & 355 & 355 & 355 & 355 & 355 \\
\hline
\end{tabular}

Note: The table reports regression coefficients of initial returns on various independent variables. A return of $10 \%$ is measured as 0.10 . In(age) is defined as the log of age of the IPO firm plus 1. In(proceeds) is defined as the log of gross proceeds of the IPO. Marketreturn is the return of the OTC index from the date of the auction until the first day of trading. In(B/M) is defined as the log of book equity to market value equity based on the lower limit of bids. Subscription 1, 2, and 3 are fitted values from auction subscription ratios from the first stage regression of subscription ratios on the relevant variables listed above, for 8904-9203, 9204-9212, and 9301-9412, respectively. Subscription ratios are the ratio of shares bid for divided by the number of shares being auctioned. Dummy9201-9212 and Dummy9301-9412 are time period dummy variables. VC-Backed is a dummy that takes on the value one when venture capitalist is among the top 10 shareholders in the IPO. SecV is a dummy that takes on the value one when a securities venture capital is the lead investor. SecVleadU is a dummy that takes on the value one when SecV $=1$ and the securities firms that is the parent of the lead venture capital company is also the lead underwriter, otherwise SecVnonleadU $=1$ (SecVleadU + SecVnonleadU $=\mathrm{SecV}$ ). BankV is a dummy that takes on the value one when a bank affiliated venture investor is the lead investor. BankVK is a dummy that takes on the value one when a parent of affiliated venture capitalist is one of keiretsu banks, otherwise BankVnonK = 1 (BankVK + BankVnonK = BankV). SBIC is a dummy that takes on the value one when a SBIC is a lead shareholder. OtherV is a dummy that takes on the value one when foreign investor or independent venture is a lead shareholder. BankDirect is a dummy that takes on the value one if a bank directly invests in the IPO firm and leads other venture capitalists and direct financial institution holdings, but excluding cases when BankV $=1$. BankDirectK is a dummy that takes on the value one when an IPO's lead shareholder belongs to keiretsu bank group, otherwise BankDirectnonK $=1$ (BankDirectK + BankDirectnonK $=$ BankDirect). Heteroskedasticity-consistent t-statistics are reported in parentheses. 
TABLE 10

P/E Ratios of IPOs versus Comparables, and Forecasted Earnings Relative to Actual Earnings

\begin{tabular}{|l|c|c|c|c|}
\hline & $\begin{array}{c}\text { Mean P/E of IPO } \\
\text { firms }\end{array}$ & $\begin{array}{c}\text { Mean P/E of } \\
\text { comparable firms }\end{array}$ & $\begin{array}{c}\text { t-test for pairwise } \\
\text { difference }\end{array}$ & N \\
\hline Non VC-backed & 30.58 & 32.55 & -1.06 & 246 \\
\hline $\begin{array}{l}\text { Securities VC-backed but parent } \\
\text { is not lead underwriter }\end{array}$ & 25.83 & 35.11 & -1.71 & 23 \\
\hline $\begin{array}{l}\text { Securities VC-backed and parent } \\
\text { is lead underwriter }\end{array}$ & 34.31 & 29.69 & 1.48 & 76 \\
\hline Bank VC-backed & 27.86 & 30.21 & -0.85 & 71 \\
\hline
\end{tabular}

\begin{tabular}{|l|c|c|}
\hline & $\begin{array}{c}\text { Percentage of forecasted } \\
\text { earnings > actual earnings }\end{array}$ & N \\
\hline Non VC-backed & 46.75 & 246 \\
\hline $\begin{array}{l}\text { Securities VC-backed but parent is not lead } \\
\text { underwriter }\end{array}$ & 60.87 & 23 \\
\hline Securities VC-backed and parent is lead underwriter & 48.68 & 76 \\
\hline Bank VC-backed & 53.52 & 71 \\
\hline
\end{tabular}

$\mathrm{P} / \mathrm{E}$ of IPO is measured using the offer price and trailing fiscal year earnings. Comparable firms are chosen on the basis of industry and size deciles from among firms that have been publicly traded for at least three years. Mean P/E ratios are calculated as the reciprocal of the mean E/P ratio, to reduce the effect of outliers. 


\begin{tabular}{l|l|l|}
\cline { 2 - 3 } & \multicolumn{2}{c}{ dominating effects } \\
\cline { 2 - 3 } $\begin{array}{l}\text { certification } \\
\text { anticipated by }\end{array}$ & $\begin{array}{l}\text { conflict of } \\
\text { interest }\end{array}$ \\
\cline { 2 - 3 } $\begin{array}{l}\text { higher } \\
\text { reputation } \\
\text { associated } \\
\text { with higher } \\
\text { P/E }\end{array}$ & $\begin{array}{l}\text { more severe } \\
\text { conflicts } \\
\text { result in } \\
\text { lower P/E }\end{array}$ \\
\cline { 2 - 3 } $\begin{array}{l}\text { unvesticipated by } \\
\text { no relation }\end{array}$ & $\begin{array}{l}\text { more severe } \\
\text { conflicts } \\
\text { result in } \\
\text { higher P/E }\end{array}$ \\
\hline
\end{tabular}

Figure 1 -- Predictions regarding price/earnings (P/E) ratios valued at the offering price. The left column lists the predictions if reputation effects dominate among underwriters, whereas the right column lists the predictions if conflicts of interest are of paramount importance. The top row lists the predictions assuming that investors fully anticipate the incentives of underwriters, and set market prices accordingly. Thus, if conflicts of interest are important, but are anticipated by investors, issues where underwriters have an incentive to set a higher offering price will show lower P/E ratios because investors rationally demand a "lemons" discount. The bottom row lists the predictions assuming that investors are not sufficiently skeptical. This gives an incentive for underwriters to set an extremely high offering price when they have a strong conflict of interest, so there will be a higher $\mathrm{P} / \mathrm{E}$, the greater is the conflict of interest. 


\begin{tabular}{l|l|l|}
\cline { 2 - 3 } \multicolumn{1}{c}{} & \multicolumn{2}{c}{ dominating effects } \\
\cline { 2 - 3 } $\begin{array}{l}\text { certification } \\
\text { investors }\end{array}$ & $\begin{array}{l}\text { conflict of } \\
\text { interest }\end{array}$ \\
no & $\begin{array}{l}\text { no } \\
\text { abnormal } \\
\text { returns } \\
\text { investors }\end{array}$ & $\begin{array}{l}\text { abnormal } \\
\text { returns }\end{array}$ \\
\cline { 2 - 3 } & $\begin{array}{l}\text { higher } \\
\text { reputation } \\
\text { leads to } \\
\text { higher } \\
\text { returns }\end{array}$ & $\begin{array}{l}\text { conflicts } \\
\text { result in } \\
\text { lower returns }\end{array}$ \\
\hline
\end{tabular}

Figure 2 -- Predictions regarding long-run abnormal returns, measured from the first closing market price. The left column lists the predictions if reputation effects dominate among underwriters, whereas the right column lists the predictions if conflicts of interest are of paramount importance. The top row lists the predictions assuming that investors fully anticipate the incentives of underwriters. As with any model assuming investor rationality, there are no predictable long-run abnormal returns. The bottom row lists the predictions assuming that investors are not sufficiently skeptical. This gives an incentive for underwriters to set an extremely high offering price when they have a strong conflict of interest. Since investors are insufficiently skeptical, investors receive a low long-run return when their expectations are systematically disappointed if conflicts of interest dominate. 


\begin{tabular}{l|l|l|}
\multicolumn{1}{c}{} & \multicolumn{2}{c}{ dominating effects } \\
\cline { 2 - 3 } certification & $\begin{array}{l}\text { conflict of } \\
\text { interest }\end{array}$ \\
\cline { 2 - 3 } $\begin{array}{l}\text { anticipated by } \\
\text { investors }\end{array}$ & $\begin{array}{l}\text { higher } \\
\text { reputation } \\
\text { results in } \\
\text { lower initial } \\
\text { return }\end{array}$ & $\begin{array}{l}\text { more severe } \\
\text { conflicts } \\
\text { result in } \\
\text { lower initial } \\
\text { return }\end{array}$ \\
\cline { 2 - 3 } $\begin{array}{l}\text { unanticipated by } \\
\text { investors }\end{array}$ & $\begin{array}{l}\text { no } \\
\text { prediction } \\
\text { conflicts } \\
\text { result in } \\
\text { lower initial } \\
\text { return }\end{array}$ \\
\hline
\end{tabular}

Figure 3 -- Predictions regarding short-run underpricing. The left column lists the predictions if reputation effects dominate among underwriters, whereas the right column lists the predictions if conflicts of interest are of paramount importance. The top row lists the predictions assuming that investors fully anticipate the incentives of underwriters. Thus, if conflicts of interest are important, but are anticipated by investors, issues where underwriters have an incentive to set a higher offering price will show a lower initial return because investors are willing to pay a market price no higher than if the offering price had been set lower. The bottom row lists the predictions assuming that investors are not sufficiently skeptical. This gives an incentive for underwriters to set an extremely high offering price when they have a strong conflict of interest. Since investors are insufficiently skeptical, investors still bid up the market price, albeit by not as much as if the issue had been priced less aggressively. 


\section{REFERENCES}

Asakura, K. (1988) Japanese Financial History (Nihon Kinyu Shi) Nihon Keizai Hyoron Sha.

Banerjee, A., T. Besley and T. Guinnane (1994) "Thy Neighbor's Keeper: The Design of a Credit Cooperative, with Theory and Evidence," Quarterly Journal of Economics.

Bank of Japan, Research Bureau (1913) Mujin Kaisha ni Kansuru Chosa (A Survey of Mujin Companies) Tokyo.

Besley, T., S. Coate and G. Loury (1993) "The Economics of Rotating Savings and Credit Associations," The American Economic Review, Vol. 83, No. 4, pp. 792-810, September 1993.

Besley, T., S. Coate, and G. Loury (1994) "Rotating Savings and Credit Associations, Credit Markets and Efficiency," Review of Economic Studies, Vol. 61, pp. 701-19.

Besley, T. and A. Levenson, (1996) "The Role of Informal Finance in Household Capital Accumulation: Evidence from Taiwan," Economic Journal, Vol. 106, pp. 39-59.

Bouman, Fritz J. A. (1977) "Indigenous Savings and Credit Societies in the Third World: A Message" Savings and Development, 1977, 1(4), pp. 181-218.

Calomiris, C., and I. Rajaraman, (1998) "The Role of ROSCAs: Lumpy Durables or Event Insurance," Journal of Development Economics, Vol. 56, pp. 207-16.

Calder, K. (1994). Strategic Capitalism. Princeton: Princeton University Press.

Campbell, C. D. and C. S. Ahn (1962) "Kyes and Mujins - Financial Intermediaries in South Korea," Economic Development and Cultural Change, pp. 55-68.

Emi, K., M. Ito, and H. Eguchi (1988) Savings and Currency (Chochiku to Tsuka), Toyo Keizai.

Geertz, C. (1962) "The Rotating Credit Association: A 'Middle Rung' in Development," Economic Development and Cultural Change, April, pp. 241-263.

Goto, Shin-ichi (1971), "Zoku Nihon no Kinyu Tokei (Japan's Financial Statistics)" (1-4) Kinyu (Finance) Zenkoku Ginko Kyokai, July-October.

Goto, Shin-ichi (1994) Mujin-Sogin Godo no Jisshoteki Kenkyu (An Empirical Study of Mergers of Mujin and Mutual Banks), Nihon Kinyu Tsushinsha.

Hamada, K. (1993) "The Showa Confusion and the Heisei Recession," (Showa Kyoran to Heisei Fukyo), Toyo Keizai. 
Japan Development Bank (1993). Policy-Based Finance, The Experience of Post-war Japan, Economic Research Institute.

Kakinuma, S. And M. Nakamura (1994). “Japan's National Mega-Bank Also Sells Stamps,” Tokyo Business, September.

Keynes (1936). The General Theory, Macmillan.

Levenson, A. and T. Besley (1996) "The Anatomy of an Informal Financial Market: Rosca

51, pp. 45-68.

Participation in Taiwan," Journal of Development Economics, Vol.

Lewin, W. (1866). A History of Banks for Savings. London: Sampson, Low, and Marston.

McKinnon, R. (1973) Money and Capital in Economic Development, Washington, DC, The Brookings Institution.

Miyamoto, M. and Takashima, M. (1991) The Financial History of the People, (Shomin no Ayunda Kinyu Shi), Osaka: Fukutoku.

Mori, K. (1982) Mujin Kinyu-shi Ron (The Collected Work of $\mathrm{K}$. Mori, Vol. 2), Tokyo, Hosei University Press.

Morishima, M. (1982) Why Has Japan 'Succeeded'? Western Technology and the Japanese Ethos, Cambridge, MA, Cambridge University Press.

Myint, H. (1964) The Economics of the Developing Countries, New York: Praeger.

Patrick (1966) "Japan, 1868-1914," in Rondo Cameron, ed., Financing in Economic Development, Oxford.

Stiglitz, J. (1990) "Peer Monitoring and Credit Markets," World Bank Economic Review.

Stiglitz, J. (1993). "The Role of the State in Financial Markets,' Proceedings of the World Bank Annual Conference on Development Economics.

Stiglitz, J. and Andrew Weiss (1981) "Credit Rationing in Markets with Imperfect Information," American Economic Review.

Teranishi, J. (1982) Japanese Economic Development and Finance, Tokyo, Iwanami.

Townsend, R. M. (1992) "Understanding the Structure of Village and Regional Economies" in L. Werin and H. Wijkander, eds., Contract Economics, Blackwell.

Townsend, R.M. (1994). "Risk and Insurance in Village 
India, "Econometrica, 62 (3).

Zenkoku Sogo Ginko Kyokai, (1971) Sogo Ginko Shi, (The History of Mutual Banks) Tokyo. 